\title{
THE FUNGAL ABILITY FOR BIOBLEACHING/BIOPULPING/BIOREMEDIATION OF LIGNIN-LIKE COMPOUNDS OF AGRO-INDUSTRIAL RAW MATERIAL
}

\author{
Ana Maria Queijeiro López*, Amanda Lys dos Santos Silva e Elane Cristina Lourenço dos Santos \\ Instituto de Química e Biotecnologia, Universidade Federal de Alagoas, Avenida Lourival de Melo Mota, Campus A. C. Simões, \\ 57072-970 Maceió - AL, Brasil
}

Recebido em 17/12/2016; aceito em 11/04/2017; publicado na web em 13/06/2017

\begin{abstract}
Lignin is present in plant cell secondary wall, associated to carbohydrates preventing their efficient hydrolysis, and cellulose pulp manufacture basically consists in breaking down the middle lamella of plant cells, individualizing fibers such as cellulose from the other biopolymers. Different levels of lignocellulose are found in plant residues and they can be decomposed by extracellular fungal lignin modifying enzymes, used as a tool to reduce waste materials in contaminated soils and effluents. In the paper mill industries, for instance, they are a suitable or complementary alternative to the traditional methods of pulping/bleaching, contributing to improve paper strength as well as to reduce the pitch content, the quantity of chemicals and the consume of electrical energy. The aim of this review was to describe the fungal degradation of lignocellulosic like-material, the non-specific enzymatic aspects of the attack of wood and agricultural wastes, the fungal ability for biosorption and bioconversion, and its applications in the pulp/paper industry and bioremediation.
\end{abstract}

Keywords: agricultural residues; biopulping; biobleaching; lignin removal.

\section{INTRODUCTION}

The pulp and paper industry has a leading participation in the gross domestic product (GDP) of several countries, such as Canada, Sweden and Brazil. ${ }^{1}$ In such countries, it corresponds to 2.0 to $3.5 \%$ of GDP, growing approximately $3 \%$ per year. $^{2}$ In Brazil, such sector is spread across 540 municipalities, with innovative and preserved forests (6.9 million of hectares, with a productivity of Eucalyptus and Pinus trees respectively of $44 \mathrm{~m}^{3}$ and $38 \mathrm{~m}^{3}$ per hectare in 2013), 220 factories generating around 128.000 direct jobs (77.000 in the industry and 51.000 in the forests) and almost 640.000 indirect jobs. ${ }^{1}$

In 2015, pulp production totaled 17.2 million tons, a $4.5 \%$ increase year-over-year, whilst paper production also remained practically stable, totaling 10.3 million tons, ${ }^{2}$ placing the Brazilian industry of paper and pulp production respectively in 4th and 9th position worldwide. ${ }^{1}$ The Brazilian pulp, wood panels and paper industries exported in 201511.5 million tons, taking advantages from the currency depreciation, recording an increase of $8.6 \%$ compared to 10.6 million tons exported in 2014 . $^{1}$

For a long time, the main source of cellulose fiber for the pulp and paper industry has been the wood, but in many emergent countries, especially in tropical areas, this is not enough available for the growing industrial demand in parallel with the increasing of the population and the gradual improvements in the level of education and sanitation conditions, which has increased the uses of paper for personal and domestic hygiene or information printing. This made necessary the intensification of the forestry production, ${ }^{3}$ however, even in such countries an accelerated replacement of the printing by electronic documents in the last decade has been slowing the expansion of planting areas.

Pulping, bleaching, and papermaking are the three major processing steps for producing pulp and paper. The ecological concern for limiting areas for conifer monocultures and availability of other raw materials (non-wood fibers), which can even pollute the environment if not removed, has carried to the use of such non-wood

\footnotetext{
*e-mail: amq1@qui.ufal.br
}

lignocellulosic feedstocks (as cotton, cereals, etc.) in paper industries. The type of pulp and intensity of bleaching used depend on the nature of feedstock and the desired quality of the final product, but in response to new environmental regulations and consumer activism, the generation of the chemical pulps has been dramatically altered over the past twenty years. Currently $43 \%, 28 \%$ and $29 \%$ of total paper production result respectively from wood, agricultural residues and paper-waste (secondary fiber), being the last one less energyconsumer and expected to be still more used with time. ${ }^{2}$ Because of this, new challenges and opportunities are developing. The primary factor contributing to such researches is the well known loss of pulping selectivity by Kraft delignification. Many researches were developed to improve the yield utilizing a single or double oxygen stage to remove high lignin content from pulps or modify the pulping process. The fungal inoculation prior to pulping offers an interesting alternative for mechanical wood pulp facilities, saving around $30 \%$ of the energy consumed, as well as improve paper strength and reduce pith content and the emissions of volatile organic compounds. ${ }^{3}$

\section{LIGNOCELLULOSIC MATERIAL: COMPOSITION AND DEGRADATIVE ENZYMES}

Cellulose, the most abundant component of lignocellulose material (35-50\% of total dry matter), is a linear polymer with amorphous and crystalline portions, formed exclusively of anhydrousglucose molecules linked by glycosidic bonds $\beta-(1,4) .{ }^{4}$ In turn, polyoses or hemicelluloses are branched polymers formed by various monosaccharides (glucose, mannose, galactose, xylose and small amounts of arabinose, uronic acids and acetyl groups), with a molecular weight and percentage (20-25\%) lower than cellulose in the lignocellulosic material (Table 1). ${ }^{4-10}$

After cellulose, lignin - a complex aromatic polymer (Figure 1), is the second main constituent of plant biomass, typical of the middle lamella of cell wall (the most external layer) of vascular plants acting as a cementing agent between fibers. It is highly recalcitrant towards both chemical and biological degradation. ${ }^{6}$ Lignin provides rigidity for stems to growth on land, and waterproofing vascular tissues for 
Table 1. Chemical composition of different lignocellulosic fibres ${ }^{7-10}$

\begin{tabular}{|c|c|c|c|c|c|}
\hline \multirow{2}{*}{ Lignocellulosic fibres } & \multicolumn{5}{|c|}{ Chemical composition $(\%)$} \\
\hline & Hemicellulose & $\alpha$-Cellulose & Lignin & Inorganic material & Silica \\
\hline Wheat straw & $23-24$ & $38-46$ & $16-21$ & $5-9$ & $3-7$ \\
\hline Oats straw & 23 & $31-37$ & $16-19$ & $6-8$ & $4-7$ \\
\hline Rice straw & 23 & $28-36$ & $12-16$ & $15-20$ & $9-14$ \\
\hline Maize stalk & $49-59$ & N/A & $22-24$ & $5-6$ & $3-5$ \\
\hline Rice husk & 21 & $38-40$ & $22-24$ & $20-22$ & $19-20$ \\
\hline Sugar cane & $14-24$ & $32-44$ & $19-24$ & $2-5$ & $3-7$ \\
\hline Kenaf & 50 & $31-39$ & $14-19$ & $2-5$ & N/A \\
\hline Oil Palm Frond & 17 & 49.8 & 20.5 & - & - \\
\hline Softwoods & $20-30$ & $40-45$ & $26-34$ & $0-1$ & 0 \\
\hline Hardwoods & $4-6$ & $38-48$ & $23-30$ & $0-1$ & 0 \\
\hline
\end{tabular}

N/A: not applicable

sap circulation, protecting cellulose against hydrolytic attack from most pathogen and saprophytic organisms.

Despite this, lignin-degrading microbes evolved simultaneously to the land colonization by vascular plants, in the Paleozoic era $(\cong$ 400 million years ago), ${ }^{11}$ which is a key step for the carbon cycle. ${ }^{12-21}$ Therefore, due to the complex composition and structure of lignin, with various oxygen functional groups giving to this biopolymer different thermal stabilities (their scission occurs at different temperatures), its degradation is strongly influenced by its nature, environmental temperature and atmosphere, which also affects the product yields. $^{12}$

The bioelimination of lignin from the cell-wall complex in wood and nonwoody lignocelluloses is very difficult, but a task of saprophytic and pathogenic filamentous fungi from the phyla Basidiomycota and Ascomycota turn this possible. These both phyla form the large subkingdom Dikarya ('higher fungi'), from which the saprobes can be roughly classified into five types: white-rot, brownrot and soft-rot fungi (subdivided into type I and II) as well as litterdecomposing and dung-dwelling (coprophilic) fungi; the latter two groups colonize the topsoil and the former ones, compact wood (trees, trunks, stumps). ${ }^{12}$ Obviously, there is also some overlapping of roles within these groups and certain species (e.g., Hypholoma fasciculare) may colonize both habitats, as well as others cause a "non-specific" rot, which may not be strictly attributed to a certain type. Fungi that colonize partially decayed wood often cause nonspecific forms of rot, ${ }^{12}$ that starts with the decomposition of cell-walls after secretion of unspecific fungal oxidative enzymes (Table 2), which can degrade lignin and other recalcitrant compounds - such as single aromatic molecules and other xenobiotics as polychlorinated biphenyls and dioxins, pesticides, phenols and chlorophenols, effluents from pulp and paper mills, dyestuffs and heavy metals. ${ }^{5,6,13}$ So that, they are used for remediation of contaminated areas or effluents. ${ }^{5}$

From the literature on fungal bioremediation, c.a. $30 \%$ focus on white-rot basidiomycetes - the main organisms able to extensively mineralize lignin, ${ }^{5,13,14}$ and the ideal model for this is the white-rot fungus Phanerochaete chrysosporium..$^{13,15}$ It is more efficient than other fungi in degrading toxic or insoluble materials, because of its simultaneous oxidative and reductive mechanisms used in many different situations, according to the type and degree of contamination and area or effluent. A number of other white-rot fungi also can degrade persistent xenobiotic compounds, e.g. Pleurotus ostreatus, P. tuberregium, P. pulmonarius, Trametes versicolor, Bjerkandera adusta, Lentinula edodes, Irpex lacteus and Agaricus bisporus. Soils may also be decontaminated from crude oil since it may be provided some lignocellulosic substrates (e.g., sawdust straw and corn cob) for the growth of fungal species. ${ }^{5,13}$ To understand the lignin attack by oxidative enzymes from white-rot basidiomycetes, synthetic lignin and simple model compounds (incorporating radioactive labelling) have been used (Table 2).

The non-phenolic lignin network can be attacked by a unique group of Basidiomycetes hemeperoxidases, ${ }^{16,17}$ such as the lignin peroxidase (LiP), which was initially described in P. chrysosporium (Sporotrichum pulverulentum) - a white-rot fungus whose genome was sequenced just due to its ability to degrade wood lignin ${ }^{18}$ leaving a whitish cellulosic residue, and a versatile peroxidase (VP) reported in Pleurotus (which species also can be able to degrade lignin selectively) and Bjerkandera species. ${ }^{19} \mathrm{VP}$ can also oxidize $\mathrm{Mn}^{2+}$, as it does manganese peroxidase (MnP) from $P$. chrysosporium, resulting in $\mathrm{Mn}^{3+}$ that oxidizes phenols. If in the presence of unsaturated lipids, $\mathrm{Mn}^{3+}$ can also oxidize nonphenolic lignin via peroxidation radicals. ${ }^{20}$ On the other hand, although $\mathrm{MnP}$ is inactive with veratryl alcohol or non-phenolic substrates, it oxidizes a bound $\mathrm{Mn}^{2+}$ ion to $\mathrm{Mn}^{3+}$ in the presence of $\mathrm{H}_{2} \mathrm{O}_{2}$, releasing $\mathrm{Mn}^{3+}$ from the active site in the presence of a chelator (mostly oxalate and malate) that stabilizes it against disproportionation to $\mathrm{Mn}^{2+}$ and insoluble $\mathrm{Mn}^{4+}$; the complexed $\mathrm{Mn}^{3+}$ ion can diffuse into the lignified cell wall, where it oxidizes phenolic components of lignin and other organic substrates. ${ }^{21}$ The molecular evolution of these peroxidases has been evidenced ${ }^{21-23}$ considering the particular characteristics of the "lignin enzymatic combustion" and the "hydrolytic biodegradation of other plant polymers (such as polysacharides)", it means, the first process generates hydrogen peroxide $\left(\mathrm{H}_{2} \mathrm{O}_{2}\right)$, which oxidizes the heme prosthetic group of the complex 1 of peroxidases. ${ }^{22,23}$

Ligninolytic fungi also express some oxidases, such as the flavoenzymes aryl-alcohol oxidase (AAO, E.C.1.1.3.7) and pyranose-2 oxidase, and the glyoxal oxidase (GLOX, a copper radical enzyme, E.C. 1.2.3.5), able to generate $\mathrm{H}_{2} \mathrm{O}_{2} \cdot{ }^{24}$ During their action on lignin model compounds, unstable cation radicals are formed, as well as breakdown of $\mathrm{C} \alpha-\mathrm{C} \beta$ and $\mathrm{C} 4-$ ether linkages, releasing aromatic aldehydes, and other reactions such as demethoxylation (methanol release) and aromatic-ring cleavage (with formation of muconate-type structures). ${ }^{5}$ GLOX of $P$. chrysosporium (Figure 2) uses products from lignocellulose degradation as reducing substrates, and the generated $\mathrm{H}_{2} \mathrm{O}_{2}$ is used by $\mathrm{LiP}^{25}$ In species of Pleurotus however, there is a continuous production of $\mathrm{H}_{2} \mathrm{O}_{2}$ during redox cycling of the extracellular metabolite anisaldehyde, ${ }^{22}$ involving myceliumassociated AAD (a NADPH-dependent dehydrogenase, E.C. 1.1.1.90) with extracellular AAO. ${ }^{26}$ The involvement of LiP in wood lignin degradation has been also understood by comparison of the genomes of $P$. chrysosporium (a large set of LiP genes) ${ }^{16,27}$ and Postia placenta (a brown-rot fungus able to remove wood polysaccharides leaving a 


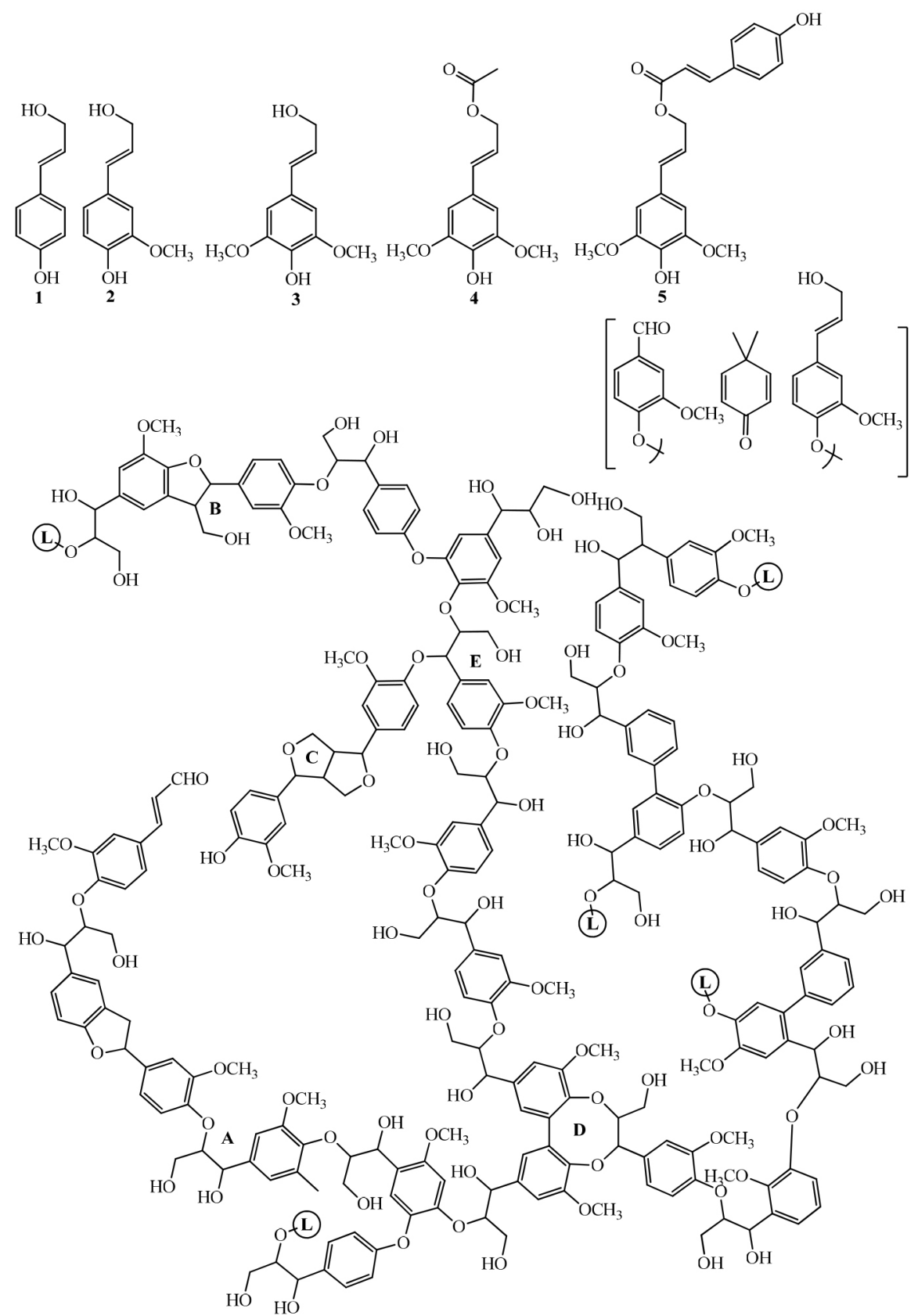

Figure 1. Structural model for the simplest gymnosperm cell-wall lignin (bottom), formed only by guaiacyl units derived from coniferyl alcohol (2), and more complex Angiosperm lignin, which include p-hydroxyphenyl and sinapyl units derived from p-coumaryl (1) and sinapyl (3) alcohols, as well as a variable amount of acylated lignin often derived from sinapyl alcohol $\gamma$-esterified with acetic (4), p-coumaric acid (5) or other organic acids. Several ether and carboncarbon inter-unit linkages are formed during the monolignols (three typical and two acylated lignin precursors) (top) polymerization resulting in $\beta$-O-4' (A), phenylcoumaran $(B)$, pinoresinol $(C)$ and dibenzodioxocin $(D)$ substructures. Linkages to additional lignin chains are indicated (L-containing circles). Minor structures (in brackets) include vanillin, coniferyl alcohol and dimethylcyclohexadienone-type units, the latter in new spirodienone substructures (Adapted from Ruiz-Dueñas \& Martinez, 2009) ${ }^{6}$

brown lignin-enriched residue), ${ }^{28}$ and the last one includes genes for oxidases, cellulolytic enzymes (Fenton Chemistry), ${ }^{28}$ a unique gene related to the low-redox-potential peroxidase of the non-ligninolytic basidiomycete Coprinopsis cinerea (CIP), and completely lacks ligninolytic peroxidase genes (lip, $v p$ or $m n p){ }^{27}$

Apart from these, in recent years, new peroxidases secreted by saprophytic basidiomycetes have been discovered. Aromatic peroxygenases (APOs, EC 1.11.2.1) catalyse diverse oxygen transfer reactions which can result in the cleavage of ethers, and nonspecific manganese-independent peroxidases (MiP), called dye-decolorizing peroxidases (DyPs, EC 1.11.1.19), oxidize recalcitrant nonphenolic substrates. ${ }^{13}$ These reactions can be relevant for the bioconversion of lignin, but the actual physiological function of APOs and DyPs is still unclear and more studies to follow their production in natural substrates (lignocelluloses) during fungal colonization are being provided. ${ }^{13}$

A third group of oxidoreductases, laccases (benzenediol oxygen oxidoreductase, EC 1.10.3.2) and related multicopper oxidases, are produced by most basidiomycetes ${ }^{29}$ and lignocellulolytic eubacteria and actinomycetes. ${ }^{30}$ These copper-containing phenol oxidases, instead of heme, requires active site $\mathrm{Cu}(\mathrm{II})$ ions for its activity, and during its mediated reactions, diphenolic compounds undergo a fourelectron oxidation, with $\mathrm{Cu}$ (II) being reduced to $\mathrm{Cu}$ (I). Therefore, 


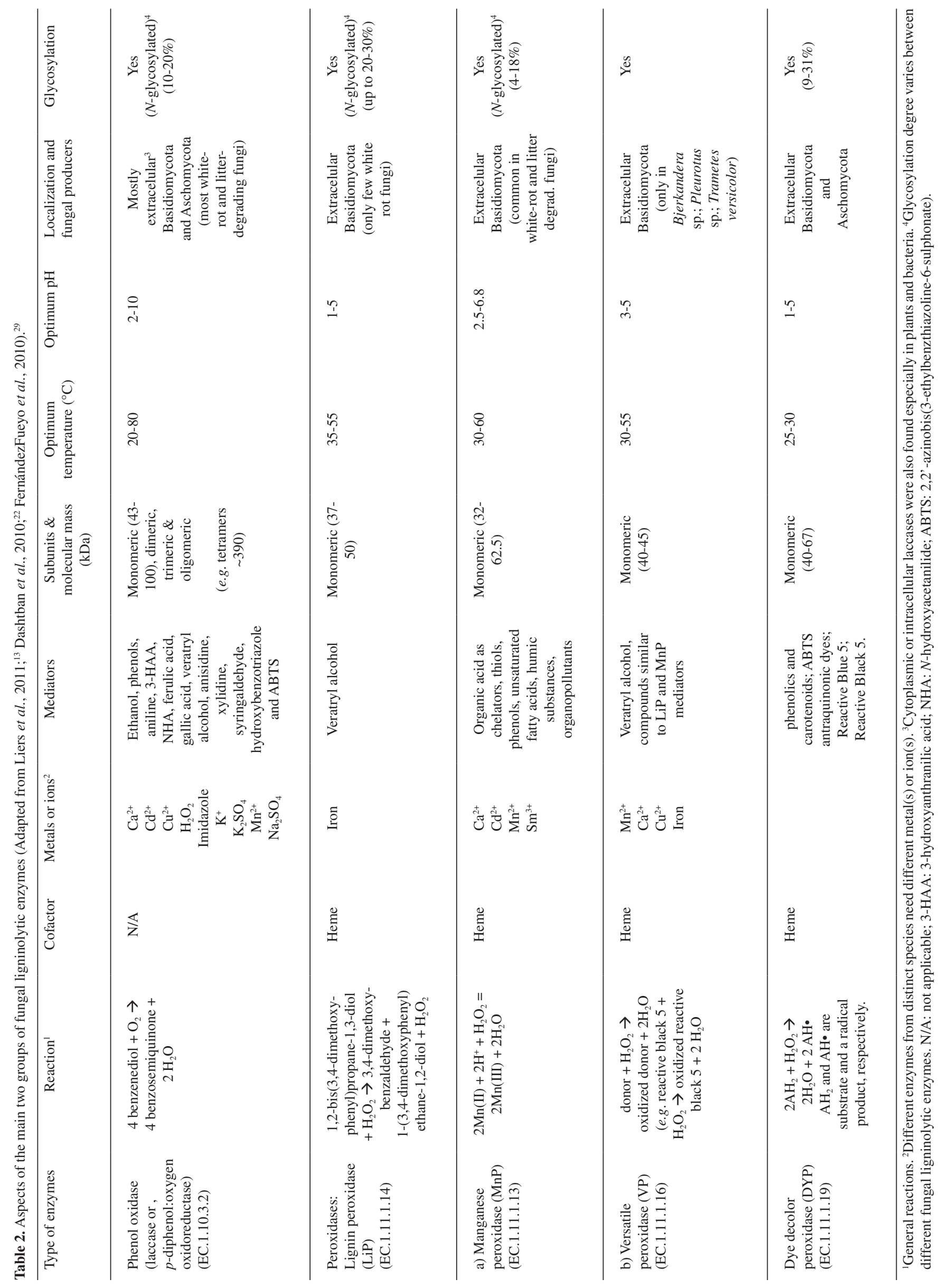


they can oxidize electron-rich substrates of phenolic and non-phenolic origin with a concomitant reduction of oxygen to water, through a radical-catalyzed reaction (Table 2 ). The direct action of laccases on lignin and other recalcitrant compounds is prevented by their low redox potential, but in presence of redox mediators this can be overcome, as well as it play several other physiological roles (morphogenesis, detoxification, humidification, etc.). ${ }^{31,32}$ Moreover, they generate hydroxyl radical [via Fenton chemistry, i.e., oxidation of organic substrates by iron(II) and $\left.\mathrm{H}_{2} \mathrm{O}_{2}\right]^{33}$ in both white and some brown rot basidiomycetes, in agreement with the presence of their genes in the genome of P. placenta. ${ }^{32,34}$

Liers et al. ${ }^{12}$ studied the decomposition of lignocellulose and the secretion of extracellular oxidoreductases in beech-wood (Fagus sylvatica) microcosms using 11 representative fungi of four different ecophysiological and taxonomic groups causing: (1) classic white rot of wood (e.g. Phlebia radiata), (2) 'nonspecific' wood rot (e.g. Agrocybe aegerita), (3) white rot of leaf litter (Stropharia rugosoannulata) or (4) soft rot of wood (e.g. Xylaria polymorpha). All strong white rotters produced $\mathrm{MnP}\left(75-2200 \mathrm{mU} \mathrm{g}^{-1}\right)$, whereas LiP activity was not detectable, but AOP and DyP were detected in the culture of A. aegerita (up to $125 \mathrm{mU} \mathrm{g}^{-1}$ ) and Auricularia auricula-judae (up to $400 \mathrm{mU} \mathrm{g}^{-1}$ ), respectively. The activity of classic peroxidases correlated to some extent with the removal of wood components (e.g. Klason lignin) and the release of small watersoluble aromatic compounds $(0.5-1.0 \mathrm{kDa})$. In contrast, laccase activity produced high-molecular mass fragments (30-200 kDa), and these differences in the biodegradation allow to distinguish the type of causal rot types (basidiomycetes or ascomycetes), being suitable for monitoring the effects of each oxidative key during wood decay.

\section{CONVENTIONAL VERSUS BIOLOGICAL PULPING AND BLEACHING - CONCEPTS AND ADVANTAGES}

Pulp is a fibrous material obtained after treating wood, fiber crops or waste paper, with separation of the cellulose fibers. There are a number of methods used to separate the wood fiber required for pulping (45\% sawmill residue, $21 \%$ logs and chips, and $34 \%$ recycled paper), ${ }^{35}$ such as mechanical, termo-mechanical (TMP), chemical or chemical-thermochemical (CTMP). ${ }^{7,36}$

As a by-product of the paper industry, therefore, lignin is most often used by paper mills as a fuel for the recovery of its energy content, however, due to its very large generated quantities, it has been increasingly considered as a potential source of chemicals. The organic phase obtained from the pyrolysis of wood (thermic treatment) or from other biomass sources, consists of a brown tar containing high molecular weight compounds derived from lignin, while the watersoluble fraction, accounting for $60-70 \mathrm{wt} \%$ of the whole oil, contains lower molecular weight substances. On the other hand, the initial step of the Kraft process - the most cost effective, versatile and efficient wood delignification method currently available, involves cooking wood chips in a solution of $\mathrm{NaOH}$ at high temperature (ca.133-180 ${ }^{\circ} \mathrm{C}$ ) and pressure, fragmenting and solubilizing most of the lignin by the cleavage of the ether linkages between the phenyl propane units. The dark color of the Kraft pulp, due to various compounds (complexed catechols, quinones, chalcones and stilbenes, which absorb visible light), justify brown paper and cardboard, which are manufactured at this stage. However, $10-15 \%$ of such linkages remain present, resulting in a heavily modified lignin. ${ }^{35}$ Currently, $\cong 70 \%$ of the world's annual pulp output is produced by the Kraft process - a versatile and efficient method available for wood delignification. Furthermore, since a large financial investment has been made to improve this technology over the past 100 years, it is unlikely that it will be replaced in the near future. ${ }^{36}$

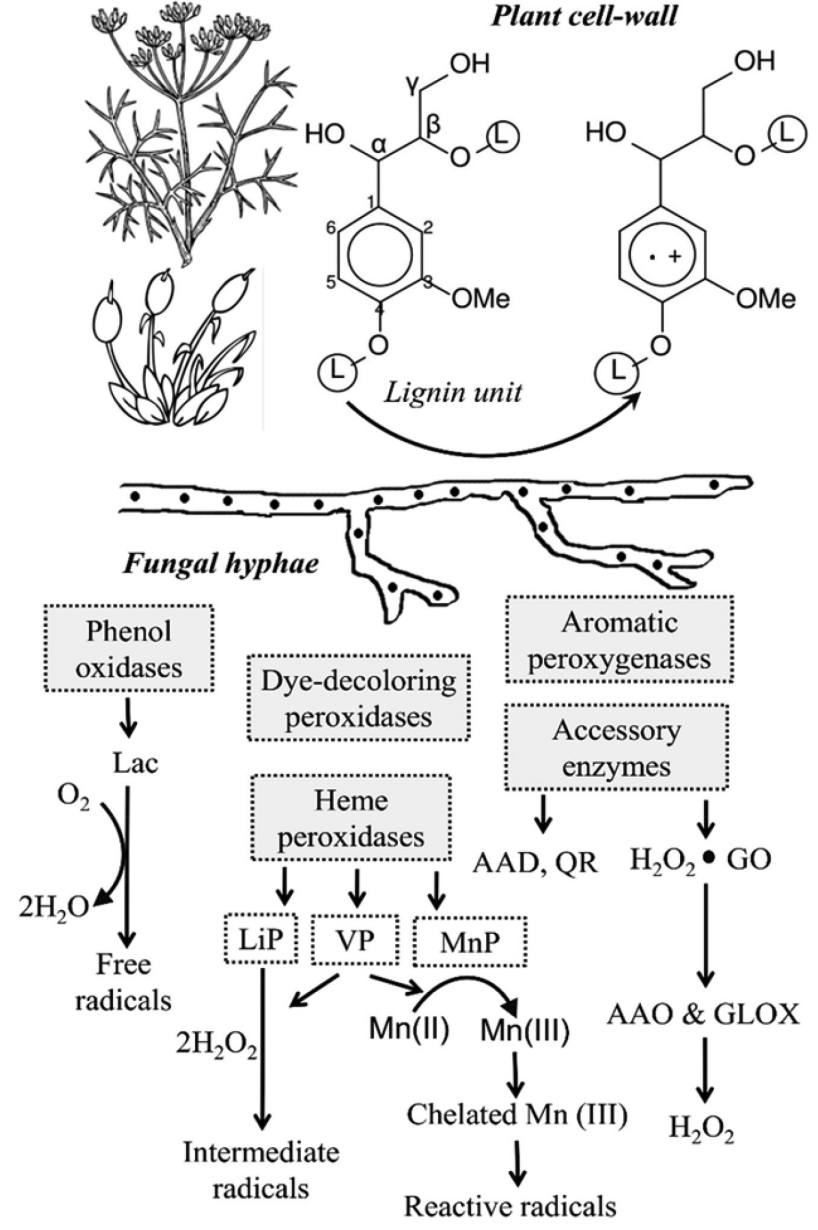

Figure 2. Diagram of enzymatic degradation of lignin (L-containing circles represent the remaining lignin polymer) by white-rot basidiomycetes such as Pleurotus. Lac: laccase, LiP: lignin peroxidase, MnP: manganese peroxidase, VP: versatile peroxidase, $\mathrm{H}_{2} \mathrm{O}_{2}-\mathrm{GO}: \mathrm{H}_{2} \mathrm{O}_{2}$-generating oxidases during redox cycling of non-phenolic aromatic fungal aldehydes, with participation of intracellular AAD; AAO: aryl-alcohol oxidase (extracellular flavo-oxidase), GLOX: glyoxal oxidase. The key step in the degradative process (Peroxidase one-electron oxidation of lignin units) results in an unstable cation radical that suffers different reactions, releasing the corresponding aromatic aldehydes (vanillin in the case of guaiacyl units) which can be intracellularly mineralized. In P. chrysosporium, the attack to lignin by LiP requires the presence of $V A$, probably as an enzyme-bound mediator, and $\mathrm{H}_{2} \mathrm{O}_{2}$ generated mainly by GLOX action. (Source: Adapted from Ruiz-Dueñas \& Martinez, $2009^{6}$ and Dashtban et al., 2010 22

Almost half of the world's Kraft pulp is subsequently bleached and extracted (various steps) with harmful organic chlorides, making the pulp suitable for white paper production but resulting in some low molecular and potentially toxic chlorophenolic compounds. Chlorine $\left(\mathrm{Cl}_{2}\right)$ and $\mathrm{O}_{2}$ react with the free hydroxyl group of phenolic-lignin subunits, whilst sodium hypochlorite and $\mathrm{H}_{2} \mathrm{O}_{2}$ react with functional groups such as double bonds. Most of the $\mathrm{Cl}_{2}$ used in the early steps of bleaching is displaced by $\mathrm{OH}^{-}$ions in subsequent alkaline extractions, but some remains as both polymeric chlorolignin $(75 \%)$ and low molecular weight chlorophenolic compounds. ${ }^{35}$ Complete removal of lignin is obtained after sequential treatment with different types of bleaching chemicals, each one attacking different sites of the lignin molecule. ${ }^{7,36}$ For each tonne of traditional pulp bleaching from softwoods, it is produced about $5 \mathrm{~kg}$ of organically bound chlorinemost of this becoming effluent. Fortunately, some governments are 
imposing limits of 'adsorbable organic halide' (AOX) allowable released as waste. Common aims are 1.5 to $2.5 \mathrm{~kg}$ AOX per tonne of pulp bleached, but the Swedish National Environmental Protection Board proposed reductions to $0.5 \mathrm{~kg}$ in 2004 and to $0.1 \mathrm{~kg}$ in 2010. A number of strategies to reduce this discharge have been taken yet, such as the replace of $\mathrm{Cl}_{2}$, ozone $\left(\mathrm{O}_{3}\right)$ and $\mathrm{H}_{2} \mathrm{O}_{2}$ into pulp bleaching sequences by chlorine dioxide $\left(\mathrm{ClO}_{2}\right)$, which produces one-fifth of the amount of $\mathrm{AOX}$ generated by the same amount of $\mathrm{Cl}_{2}$ used. More efficient pulping methods prior to bleaching also helps to reduce the amount of lignin in the bleaching stages. ${ }^{37}$

On the other hand, several microorganisms take advantage of plant biomass and several types of organic matter, using a broad spectrum of enzymes. "Biopulping" (Figure 3) is defined as the treatment of wood chips and other lignocellulosic material with natural wood decay fungi, prior to TMP. ${ }^{38}$ This idea came in the 1950 's, upon the realization that certain white-rot fungi were involved in the wood attack, leaving cellulose with a low degree of polymerization and some lignin, producing a very weak paper. It took a long time to solve the details of enzymatic delignification and identify a microbe suitable for the technical requirement of a functional industrial. ${ }^{37}$

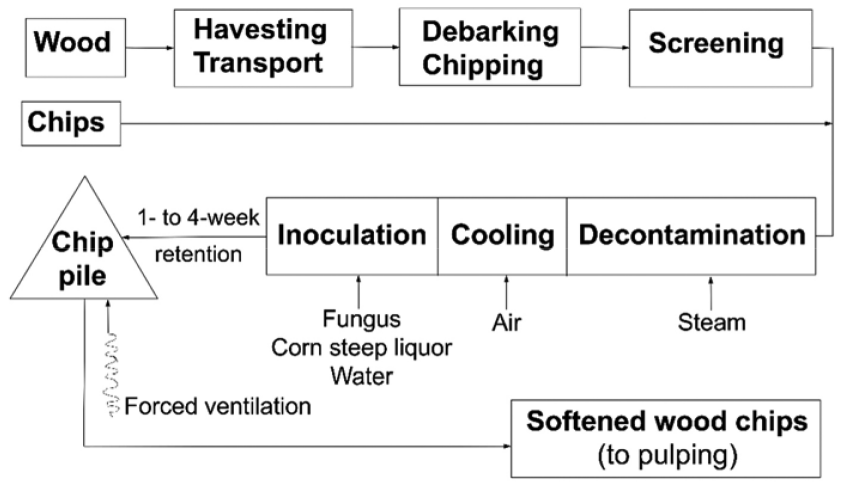

Figure 3. Scheme of the general stages involved in biopulping operation (Scott et al., 1998) $)^{38}$

Biological methods of pulp pre-bleaching using xylanases provide the possibility of selectively removing up to $20 \%$ of xylan from pulp and saving up to $25 \%$ of chlorine. Pulp can also be "biobleached" with white-rot fungi or their enzymes, enabling chemical savings and the establishment of a $\mathrm{Cl}_{2}$ free bleaching technology. For this, the use of laccase/mediator system has strong interest, in part due to the discovery of new mediators for such enzyme action, but also for "biobleaching" studies to eliminate $\mathrm{Cl}_{2}$ in the pulp clearing process. In this way, new environmentally benign elemental $\mathrm{Cl}_{2}$ free (ECF) and totally $\mathrm{Cl}_{2}$ free (TCF) bleaching are required for reducing the hemicellulose content in dissolving pulp, adjusting the brightness at a high level and, simultaneously, improving the quality of the effluents in terms of toxicity and AOX. ${ }^{34-36}$

Researches looking for degradative enzymes in fungi isolated from detritus of the leaves of the mangrove Rhizophora apiculate, for instance, showed that all the isolates produced cellulases, while some produced xylanase, pectin lyase, amylase and protease. A marine-derived fungus NIOCC \#3 (Aspergillus niger) isolated from such substrates produced a thermostable $\left(\right.$ at $55^{\circ} \mathrm{C}$ ) xylanase active at $\mathrm{pH} 8.5$ and cellulase-free, effective in biobleaching. The crude culture filtrate containing $580 \mathrm{U} \mathrm{L}^{-1}$ of xylanase could bring about bleaching of sugarcane bagasse pulp by a 60 min treatment at $55^{\circ} \mathrm{C}$, resulting in a decrease of ten units in the Kappa number $\left(\mathrm{K} \mathrm{n}^{\circ}\right)$ and $30 \%$ reduction in chlorine consumption during bleaching. ${ }^{39} \mathrm{The} \mathrm{K} \mathrm{n}^{\mathrm{o}}$ index is considered a measure of lignin content in wood.

\section{Fungal potential for biopulping and biobleaching}

For a fungus be able to work commercially in biopulping and biobleaching it should display: a) relatively fast growth rate; b) ability to grow on both hardwood and soft wood; c) preferred activity against hemicellulose and lignin associated with low activity on cellulose; d) ability to degrade extractives, inability to elicit allergies (since the fungal growth on chip pales causes health problems for the workers in the pulp and paper factories); e) aggressive competition against other microorganisms that could damage the cellulose and give other problems; f) low pigmentation that might reduce pulp brightness; g) good ability to sporulate in order to facilitate the inoculation of the wood chips. ${ }^{36}$ For this, many distinct protocols have been developed, including differential staining and microscopy ${ }^{40}$ such as scanning and transmission electron microscopy (SEM and TEM) ${ }^{41}$ determination of weight loss and analysis of degradation products. ${ }^{40-43}$ However, none of these procedures can be used to accurately predict the influence of the fungal treatment in the chemical conditions of the pulping - an improvement in cooking liquor penetration would minimize this. ${ }^{44}$

The decayed wood has a brown, soft appearance that is cracked and checked when dry. Soft rot fungi can tolerate a wide range of temperature, humidity and $\mathrm{pH}$ conditions, and act on a large number of wood substrates, occurring in soils and other environments. They are particularly active under conditions that discourage the activity of white and brown rot fungi, it means, they are more common in hardwood than in softwood, probably because of their differences in the lignin content - the methoxyl index of hardwood lignin is usually

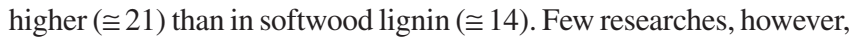
were conducted to evaluate the changes in the structural and chemical composition of wood degraded by soft-rot fungi. ${ }^{45-52}$ Two forms of soft-rot, produced by fungi such as ascomycetes and deuteromycetes (imperfecti fungi), have been described - type I consists of biconical or cylindrical cavities formed within secondary walls, while type II refers to an erosion form of degradation not involving the high level of guaiacyl units in the middle lamella of coniferous wood (in contrast to nonselective white-rot fungi). ${ }^{46}$ Although soft-rot fungi degrade lignin and polysaccharides, they do this very slowly, ${ }^{46,47}$ so that their LiPs or laccases may not have the oxidative potential to act on the recalcitrant guaiacyl lignin, but on syringyl lignin..$^{48}$

Ascomycetes from genera such as Daldinia, Hypoxylon, and Xylaria, previously regarded as white-rot fungi but currently classified as soft-rot fungi (due to the typical type II soft rot), primarily occur on hardwood. The most efficient fungus of this group, Daldinia concentrica, two months after its inoculation was able to cause weight losses higher than $53 \%$ in birch wood, and within 4 months it produced the highest lignin loss (44\%) when the weight loss was $77 \%$. However, in pine wood this fungus caused a low degradation (only $2.5 \%$ weight loss). ${ }^{47}$

Microfungi (deuteromycetes and certain ascomycetes), such as Penicillium chrysogenum, Fusarium oxysporum, $F$. solanii and F. proliferatum), which degrade mainly carbohydrates in soil, forest litter and compost, also degrade lignin in these environments. ${ }^{48-50}$ Biodegradation of wood by two soft-rot fungi, A. niger and $P$. chrysogenum, in soil which was artificially infested, was confirmed by (SEM). It was found that softwood is more resistant to fungal attack than the hardwood in the early stages, but in the late infection stages it can also degrades severely. This was interpreted as the soil accelerates the rate of decomposition because the fungi accumulate in the degraded parts of the cell walls. The author of such studies found that $A$. niger and $P$. chrysogenum degrade wood species, resulting in a gradual breakdown of wood structure. ${ }^{51}$ Surprisingly, soft-rot fungi tolerate low moisture to cause extensive decay in the wood samples, and there were differences regarding hyphal colonization and wood 
degradation patterns between both fungi - A. niger produced softrot decay type I (cavity formation) and type II (erosion), while $P$. chrysogenum caused only soft-rot decay type II. ${ }^{45,51} \mathrm{~F}$. proliferatum, on the other side, after $30 \mathrm{~d}$ mineralized $3.5 \%$ of a ${ }^{14} \mathrm{C}$-(ring)-labeled DHP (dehydrogenation polymerizate, i.e. synthetic lignin) and $10 \%$ of ${ }^{14} \mathrm{Cb}$-labeled DHP, with a maximum degradation during primary metabolism. ${ }^{52}$

The main extracellular lignolytic enzymes produced by these fungi (peroxidases and oxidases) $)^{53-55}$ may not be so efficient as those of white-rot fungi, but have special properties. The thermophilic ascomycete Thermoascus aurantiacus, for instance, commonly grows in the heated parts of wood chip piles in Scandinavia, and also in abundant and low-cost agro-industrial and forest residues/wastes. One isolate from Eucalyptus grandis wood in Brazil ${ }^{56}$ showed unusual properties, i.e., it degrades extractives of eucalyptus and bleaches the Kraft pulp of this wood tree, expressing extracellular phenol oxidase with an optimal activity (higher levels) in a pH 2.6-3.0 and temperature up to $70-80^{\circ} \mathrm{C} .{ }^{55,56}$

On the other hand, the largest group of lignocellulolytic (rotter) fungi belong to the orders Agaricales and Aphyllophorales (phylum Basidiomycota), usually grouped in white and brown wood-rots. Their reproduction usually occurs by haploid basidiospores (the primary mycelium after spore germination is also haploid). Dikaryotic secondary mycelium arises as the result of hyphal fusion between different primary mycelium and is identified by the presence of clamp connections at the septum. ${ }^{57,58}$ Decay by these fungi in natural environment starts by the surface deposition of spores or mycelial fragments that are carried by the wind, water, or by insect or animal vectors; or because of mycelial growth into wood in direct soil contact. Germination of spores and/or the initiation of mycelial growth into the wood will not occur until appropriate moisture (above the fiber saturation point, but the cell lumen void space is not saturated) and temperature $\left(10-45^{\circ} \mathrm{C}\right)$ are reached. Optimal conditions for growth and degradative activity vary with fungal species and there are many other factors that play a role in whether decay will start, let alone grow into wood, and then begin metabolite production for initiation of the decay process. ${ }^{59}$

Brown-rot is the most common and destructive type of decay in structural wood products - preferentially coniferous, in the northern hemisphere, and they account for less than $10 \%$ of the taxonomic diversity of lignocellulolytic basidiomycetes. Comparative and functional genomics of wood decay fungi indicate that the evolution of brown-rot saprotrophy was accompanied by losses in key enzymes implicated in biomass breakdown in white rot, especially cellulases and lignin-modifying enzymes. They distinctly modify lignocellulose and completely hydrolyze polysaccharides (saccharification) through a unique mechanism, without secreting an exo-acting glucanase, with accumulation of the degradation products (the fungus does not use all of them in the metabolism), and without removing lignin..$^{60}$ Usually, the decay involves a catalytic system via Fenton chemistry, with production of hydroxyl radicals that act on wood elements. $\mathrm{LiP}$ and $\mathrm{MnP}$ are expressed in the brown-rot fungus Polyporus ostreiformis, which removed $18.6 \%$ of the lignin from rice straw within 3 weeks. ${ }^{61}$ Laccase gene-specific sequences also have been detected in brown-rot fungi. ${ }^{62}$

In spite of the enormous economic lost in the wood sector caused by this group of fungi, the number of researches with them are more restricted than with the white-rot fungi. Many brown-rot fungi such as Serpula lacrymans, Coniophora puteana, Meruliporia incrassata, and Gloeophyllum trabeum are destructive to wood from buildings and other structures, which become dark, shrink, and typically broken into brick-shaped or cubical parts that easily fragment themselves into brown powder (modified lignin). ${ }^{45}$ C. puteana and S. lacrymans, two of the most harmful fungi occurring in wood in temperate regions, prefer softwood to hardwood as substrates. Early in the decay process, their hyphal mycelium penetrates through existing pores in wood cell walls and invade the cell lumen from one to another cell. The hyphae are in close connection with the S3 layer. In brown rot, the decay process is thought to affect the S2 layer of the wood cell wall first. ${ }^{63}$ Lignin from this brown-rotted wood is more reactive than native lignin due to the increased content of phenolic hydroxyl groups. ${ }^{59}$ As for white-rot fungi, brown-rot fungi degradative capabilities rely on radical formation, especially in the early stages of decay, when low $\mathrm{pH}$, and the production of organic acids, increasing the alkali solubility of lignin, and the decay is enhanced by high oxygen tension. ${ }^{64-67}$

Analogously to different groups of white-rot fungi that use different ligninolytic mechanisms, brown-rot fungi also possess different wood degradation processes. The first group involves Gloeophyllum trabeum (syn. Lenzites trabea) type fungi, whilst the second includes Coniophora puteana and Poria (Postia) placenta type fungi. G. trabeum causes a significant release of alkali-soluble lignin, especially during the first week of its growth on pine sawdust. ${ }^{68}$ Probably, the initiators of both cellulose and lignin breakdown are low molecular weight compounds that readily diffuse from the hyphae and penetrate into the wood cell to start decay. ${ }^{69-72}$ These initiators may be phenolates or other iron-chelating compounds (siderophores), oxalate, and simple aromatic compounds. ${ }^{6,73-77}$ Although some brown-rot fungi accumulate oxalic acid, which causes a significant $\mathrm{pH}$-decreasing, this do not happens with $G$. trabeum, probably due to enzymes that degrade oxalate, ${ }^{75}$ once this fungus may use oxalic acid as a proton donor for enzymatic and non-enzymatic hydrolysis of polysaccharides and as a chelator for a $\mathrm{Fe}(\mathrm{II})-\mathrm{H}_{2} \mathrm{O}_{2}$ system, generating hydroxyl radicals. ${ }^{71}$ G. trabeum showed an unusual ability to rapidly degrade an aliphatic polyether via extracellular one-electron oxidation, ${ }^{76}$ and it produces the simple aromatic compounds 4,5-dimethoxy-catechol and 2,5-dimethoxyhydroquinone, ${ }^{77}$ which may serve as ferric chelators, oxygen-reducing agents, and redox-cycling compounds. ${ }^{78}$ It also produces 2,5-dimethoxy-1,4-benzoquinone. ${ }^{79}$

In $C$. puteana, probably cellobiose dehydrogenase $(\mathrm{CDH})$ reduces intracellularly Fe (III), and then its hyphae secretes at some distance $\mathrm{Fe}(\mathrm{II})$, forming a $\mathrm{Fe}(\mathrm{II})$-oxalate complex that may reacts via Fenton chemistry, with formation of hydroxyl radicals ${ }^{80}$ that can remove methoxyl groups from lignin and produce methanol, and hydroxylate aromatic rings, resulting in increased phenolic hydroxyl groups, which makes the modified lignin more reactive. ${ }^{5,64}$ The presence of carboxyl and carbonyl groups can also be evidenced by the increase of the oxygen concentration. ${ }^{65}$ In spruce wood, the main degradation of carbohydrates, with hemicelluloses removal faster than cellulose removal, was seen after the infection with $P$. placenta, by using Solid-state Cross-Polarization Magic Angle Spinning Carbon-13 Nuclear Magnetic Resonance (CP/MAS ${ }^{13} \mathrm{C}$-NMR) spectrometry, ${ }^{81}$ resembling the findings with $G$. trabeum. ${ }^{62}$ P. placenta further caused demethoxylation of spruce lignin, with an increase in vanillin-like structures and alpha-carbonyl moieties, and none evidence for ring opening. ${ }^{81}$ Birch wood was degraded in a different way, and the cleavage of lignin beta-O-4 linkages was the most prominent reaction occurring, rather than demethoxylation of lignin. ${ }^{81}$

A wood environment also may stimulates the level of demethoxylation of lignin model compounds by brown-rot fungi. When G. trabeum was cultivated under optimized conditions on pine wood flakes, the evolved ${ }^{14} \mathrm{CO}_{2}$ from ${ }^{14} \mathrm{C}$-methylated lignin was about $30 \%$ in $52 \mathrm{~d},{ }^{59}$ and $30 \pm 60 \%$ of the applied radioactivity was released as ${ }^{14} \mathrm{CO}_{2}$ within 8 weeks from a nonphenolic $\left(4-\mathrm{O}^{14} \mathrm{CH}_{3}\right)$-labeled beta-O-4 dimer. ${ }^{82}$ P. placenta produced ${ }^{14} \mathrm{CO}_{2}$ from $\mathrm{O}^{14} \mathrm{CH}_{3}$-labeled vanillic acid rather well, but poorly from the beta-O-4 dimer, only $3 \%$ as ${ }^{14} \mathrm{CO}_{2}$ within 4 weeks under similar conditions. ${ }^{82}$ 
On the other hand, there are about 10,000 species of whiterot Basidiomycetes, with varying capacities to degrade all the components of wood: lignin, cellulose, and hemicelluloses. Isolated oxidative enzymes from the same origin may become valuable tools for more specific and targeted chemical reactions in fibre bleaching and fibre modification and have been tested for possible applications in the pulp and paper industries. Many white-rot fungi colonize cell lumina and cause cell wall erosion. Lesions coalesce as decay progresses, forming large voids filled with mycelium, being referred to as non-selective or simultaneous rot (when all the wood cell wall components are broken down at approximately the the same rate and lead to an erosion of the secondary wood cell walls). ${ }^{45}$ Trametes (syn. Coriolus, Polyporus) versicolor is a typical simultaneous-rot fungus. ${ }^{59}$ Contrary to them, selective white-rot fungi initially degrade only lignin and then, in later stages, hemicelluloses. A cellulose-enriched fibrous material with intact cellular structures remains. ${ }^{59}$

A study using SEM and chemical analyses following TAPPI Standard Methods and Fourier Transmission Infra Red (FT-IR), comparing the ability of two species of white rot fungi, originally isolated from the tropical Malaysia forest (Pycnoporous sanguineus and Oxyporus latemarginatus FRIM 31), in degrade lignin of kenaf chips for a period of $1,2,4,8$ and 16 weeks, evidenced the fungal colonization. In the first 4 weeks, the weight loss was similar (30$31 \%$ ) for both fungi-inoculated kenaf, but after that, it was higher in the O. latemarginatus FRIM 31-treated kenaf. Monitoring of the three major lignolytic enzymes (MnP, LiP and laccase) for both fungi over the different time interval of incubation showed that $P$. sanguineus produced only laccase, reducing its secretion after 4 weeks but turning its activity higher. $O$. latemarginatus FRIM 31 secret Lip and $\mathrm{MnP}$ in decaying kenaf, but not laccase. Differences in the weight of kenaf (degradation) may result by distinct biochemical systems such as the enzymatic ones. The contents of cellulose, hemicelluloses and lignin in the treated kenaf chips were reduced in both treatments. The results showed that $O$. latemarginatus FRIM 31 had a higher ability to degrade lignin when compared to $P$. sanguineus. ${ }^{64}$ Other authors evaluated the pro-oxidant activity of enzymatic extracts from cultures of Ceriporiopsis subvermispora on wood plus calcium and oxalic acid or soybean oil, observing that significant activity of $\mathrm{MnP}$ was required to promote lipid peroxidation and wood delignification. ${ }^{83}$

Several factors contribute to the different white-rot fungi show distinct mechanisms to degrade lignin in a broad range of plants. ${ }^{40,41,84}$ Some, such as Phellinus nigrolimitatus, predominantly do this without a substantial loss of cellulose, and cause white-pocket or white-mottled type of rot. ${ }^{45,84,85}$ There are also those able to attack both components of the same wood, such as Ganoderma applanatum, Heterobasidion annosum and Phellinus pini, ${ }^{45}$ and some species can cause selective lignin-removal in one site and simultaneous lignin:cellulose-removal in another site of the same wood, such as P. chrysosporium and Ceriporiopsis subvermispora. ${ }^{42}$ Even different strains of a single species can show considerable variation, where the ratio lignin \pm hemicellulose \pm cellulose decayed by a selected fungus can differ enormously. ${ }^{42} \mathrm{~A}$ poor delignification selectivity results in a high content of carbohydrates to be degraded during biotreatment, decreasing the pulp yield ${ }^{86}$ Degradation pattern is also known to depend on environmental conditions. Moreover, some white rot fungi seem to switch from selective to simultaneous degradation over time. ${ }^{87}$

With the purpose to find suitable fungi for biopulping of wood or straw, ${ }^{88}$ several studies revealed isolates that, under certain conditions, degrade lignin preferentially to cellulose, such as $P$. chrysosporium, ${ }^{42,64}$ C. subvermispora, ${ }^{42,64}$ C. rivulosa (Physisporinus rivulosus), ${ }^{89}$ Pycnoporus cinnabarinus, ${ }^{89}$ Pleurotus ostreatus, ${ }^{19}$ P.eryngii, ${ }^{19,90}$ Phlebia radiate, ${ }^{90}$ P.tremellosus (syn. Merulius tremellosa), ${ }^{42,90} P$. subserialis, ${ }^{91}$ Phellinus pini,${ }^{64}$ and Dichomitus squalens. ${ }^{64}$ Using a
Fourier Transform Near Infrared (FT-NIR) spectroscopic technique, lignin loss of sterilized spruce wood shavings $(0.4-2.0 \mathrm{~mm}$ particle size), degraded by various white rot fungi [D. squalens, three Phlebia species ( $P$. brevispora, $P$. radiata and $P$. tremellosa), three strains of $C$. subvermispora as well as the ascomycete $H$. fragiforme and the basidiomycete $O$. latemarginatus] was monitored during two weeks. ${ }^{92}$ All the tested fungi were able to reduce significantly the lignin content during the first week. The delignification detected after 2 weeks ranged from $7.2 \%$ for C. subvermispora (FPL 105.752) to $2.5 \%$ for $P$. radiate, being significant $(\mathrm{P}=95 \%)$ after the third day of the inoculation with $C$. subvermispora and P. tremellosa. ${ }^{92}$

Also, the fungal or enzymatic treatment of raw material can be solid or liquid state fermentation (SSF or LSF). As previously mentioned, $C$. subvermispora is a model fungus for selective lignin degradation, with an accumulation of calcium oxalate and $\mathrm{MnO}_{2}$ when the decay proceeds, ${ }^{45,59,93,94}$ and the most important ligninolytic enzyme from this species and many other lignin-selective whiterot fungi is MnP. However, in nature, this group of fungi is more commonly found on angiosperm than on gymnosperm wood species. ${ }^{95}$ Usually guaiacyl $(\mathrm{G})$ units of lignin are more resistant to degradation than syringyl (S) units. In fibers, secondary walls contain a high proportion of S-lignin whilst the middle lamella contains a high concentration of G-lignin. When C. subvermispora and P. eryngii were grown on straw, they remove partially the middle lamella of cells (G-lignin), while P. radiata removed secondary cell walls (S-lignin), as can be seen by TEM. ${ }^{96}$

Several basic research on lignin degradation were provided using the corticioid fungus $P$. chrysosporium. ${ }^{23,59,97}$ However, with the advances of the studies using different fungi, it was seen that both the physiological conditions for lignin degradation and the enzyme systems expressed are fungus-specific, differing from those of $P$. chrysosporium.${ }^{97}$ Divergences may be related to the ecology and/or taxonomic position of the fungi, such as the substrate specialization (hardwood, softwood, or certain wood species, heartwood or sapwood), the stage of degradation, etc. In poplar wood, for instance, Ganoderma lucidum produces MnP, but it is not expressed by this fungus in pine wood medium. ${ }^{98}$ It has the genetic potential to produce LiP since lip-like sequences were found in Southern hybridization, but the activity of this enzyme could not be detected. Studies with fungi from the genera Stropharia and Agrocybe showed that mineralization of ${ }^{14} \mathrm{C}$-(ring)-labeled synthetic lignin (DHP) was about half of the level obtained with wood-inhabiting white-rot fungi, and the main ligninolytic enzymes in litter-decomposing fungi such as A. bisporus and Stropharia rugosoannulata are laccase and MnP. ${ }^{99,100}$ Laccase was the only ligninolytic enzyme in Marasmius quercophilus. ${ }^{101}$

The selected ligninolytic fungi for degradation of wood chips or non woody plants such as kenaf, straw, and corn stalks, should have preferred action against hemicelluloses and lignin united with low activity on cellulose. ${ }^{7}$ The chips are briefly steamed to reduce native microorganisms, cooled with forced air, and inoculated with the biopulping fungus before be piled and ventilated with filtered and humidified air for 1-4 weeks prior to processing. ${ }^{7}$

The lignocellulosic biomass from forests, wood, and agroindustrial residues is a low cost source of energy with several uses. Agriculture based fibers are mainly relevant in countries where demand for pulp and paper is increasing but the wood resources are restricted. ${ }^{37}$ Potential non woody species for fiber production belong to the families of Gramineae, Leguminosae, and Malvaceae. ${ }^{102}$ From these, most attention has been given to Gramineae and other monocotyledons, which have high fiber content with similar properties of the hardwood. ${ }^{103-106}$ The stem component of grasses, followed by the sheaths and then the leaves, has the highest pulp 
yield, fiber length, and brightness. ${ }^{102}$ Currently, the fiber markets for perennial grasses include their use for livestock bedding, "straw bale" housing, and as a compost substrate for mushroom production. Potential markets include energy industries as well as the pulp and paper and composite factories. ${ }^{104}$ Several of the grass species wildly grow in Gujarat (India) grasslands, for instance, are fast-growing with large amount of biomass but very unpalatable, being refuted by livestock but used as fuel. ${ }^{106}$

Sugarcane is one of the several species of tall perennial true grasses of the genus Saccharum, native to the warm temperate to tropical regions of South Asia and Melanesia, used for sugar and ethanol production. In 2014, The Food and Agriculture Organization (FAO) estimates that in the 5 major producer countries, it was cultivated on about $20.484 \times 10^{6}$ hectares, with a production of $1.443 \times 10^{9}$ tons, being Brazil the largest producer in followed by India, China, Thailand, Pakistan and Mexico. ${ }^{107}$ It is one of the plants with the highest bioconversion, being able to efficiently fix solar energy, yielding some 55 tonnes of dry matter per hectare of land annually. After harvest, the crop produces sugar juice and bagasse $(300 \mathrm{Kg}$ per tonne of sugarcane crushed), it means, the fibrous dry matter (biomass) with potential as fuel (energy production). ${ }^{107}$ Bagasse can also be used as an alternative source of pulp for paper production. ${ }^{108}$

A strain of Cryptococcus albidus known to produce xylanase, laccase and $\mathrm{MnP}$ in SSF was used for biopulping of bagasse (the byproduct of sugarcane industry) under partially sterilized conditions to access its potential industrial application. ${ }^{109}$ Enzyme analysis of bagasse samples previously inoculated or not (control) with C. albidus was carried out at different time periods (days 15, 30, and 60). The proportion of cellulose degrading enzymes was found to be much lower in the inoculated samples (3.0-3.5\%) than is the control ones (21-56\%). SEM demonstrated surface colonization and pit formation, whilst FT-IR indicated the chemical modification of bagasse. The signature peak for cellulose was found to be prominent in C. albidustreated samples, and denaturing gradient gel electrophoresis (DGGE) confirmed the presence of $C$. albidus throughout the period of the studies, suppressing the growth of a native population. After 60 days, when both control and treated bagasse were given a Kraft pulping, the inoculated samples had the $\mathrm{K} \mathrm{n}^{\circ}$ decreased by $42 \%$ while in control samples it was found to be decreased by $39 \%$ only. There was increase in viscosity $/ \mathrm{K} n^{\circ}$ ratio after treatment. ${ }^{109}$

Banana residues is one of the main fruit wastes available worldwide, and includes the leaf and pseudo stem (commonly used for paper making), and the peel resulting from banana processing. Such waste is used for the production of ligninolytic enzymes such as laccase, by the white rot fungus Trametes pubescens, ${ }^{110}$ or cellulolytic enzymes, ${ }^{104}$ but the level of ligninolytic enzymes is higher. Also rape seeds are the major waste from the grape processing units, and they are substrate for laccase, Lip and MnP production. ${ }^{111,112}$

Unlike the weak chemically softened fiber, fungal treatment produced soft, whiter fibers with better tensile strength and elongation (44.6-44.8\%) properties. ${ }^{113}$ White-rot Basidiomycetes were found to have a great potential for this process, ${ }^{7,114-118}$ which is an environmentally kind mean of improving both the cost and quality of the pulp produced. In the past few years, two well known white-rot basidiomycetes, Phellinus pectinatus and Daedaleopsis confragosa, which are selective lignin degraders, were studied for the process of biopulping of pretreated raw material. ${ }^{119}$

Wood blocks, bamboo (Gramineae) culm, wood shavings and culm of Sorghum halepense (Gramineae) were used in a mixture of raw material with different sort of lignin. As quantified by several extractive procedures there is less lignin in grasses than in woody plants. ${ }^{120-122}$ Cellular composition of grass culm is mainly occupied by parenchymatous cortex in which the vascular bundles ensheathed with the lignified fibers are embedded. Before the pre-treatment of raw material with fungi, six different modified processing of raw material have been attempted and evaluated. Two combinations of raw samples (1- Bamboo: wood shavings; and 2-Bamboo: wood shavings: Sorghum halepense culm) were prepared to four different pre-treatments. The rate of lignin degradation was highest when these raw were inoculated with fungi but not pre-treated, being cost effective. A supplement of potato-dextrose broth medium carried to the success of D. confragosa in the delignification of the raw material during an appropriate time of 20 days, and the presence of silica in the grasses does not hinder degradation process.

When pineapple leaf fiber (PALF) was inoculated with $C$. subvermispora, the individual fibers had good tensile properties $(0.3 \%)$ and favorable structural properties on FT-IR spectroscopy. The PALF paper also achieved desirable tear index value and uniform morphology when compared to the ones produced by conventional chemical pulping. This new method of pulping PALF finds applications in paper and packaging products which requires biofriendly characteristic and low cost. ${ }^{123}$

On the other hand, whilst the pretreatment of the Oil Palm Empty Fruit Bunches, for 30 days, with the white-rot fungus Marasmius sp., allowed the removal of the lignin by $35.94 \%$, the contents of cellulose and hemicelluloses relatively did not suffer any changes in the empty fruit bunch (EFBs). The pre-treatment carried out to a $\mathrm{K} \mathrm{n}^{\circ} 31.10$, while the control not pre-treated exhibited a $\mathrm{K} \mathrm{n}{ }^{\circ}$ 38.63. ${ }^{124}$ In a previous work using oil palm biomass as the substrate for the pretreatment or not (control) with the fungus T. versicolor, during 1, 2, 3, and 4 weeks, the highest levels of laccase, $\mathrm{MnP}$ and LiP activities were respectively $218.66 \mathrm{U} \mathrm{L}^{-1}, 162.10 \mathrm{U} \mathrm{L}^{-1}$ and $42.56 \mathrm{U} \mathrm{L}^{-1}$, while the levels of cellulase and hemicellulase activities were insignificant in all extracts $\left(53.30\right.$ and $1.50 \mathrm{U} \mathrm{L}^{-1}$, respectively). ${ }^{124}$ Hand sheet properties were also improved significantly by such fungal treatment, being the the weight, lignin, cellulose and holocellulose losses of respectively $8.45 \%, 9.35 \%$, $4.58 \%$, and $7.2 \%$. Images from SEM indicated a simultaneous type of decay pattern involving cell wall breakdown combined with lignin modification. ${ }^{17}$ In the same research, when the chips were pulped mechanically, the $\mathrm{K} \mathrm{n}^{\circ}$, pulp yield, and screened pulp yield decreased significantly and paper strength increased marginally with the exposure time. T. versicolor, thus, is found a powerful fungus for use in large-scale biopulping processes. ${ }^{125}$

With eucalyptus wood, the biopulping was studied using $C$. albidus for the pre-treatment during 15, 30, and 60 days. The production of endo-glucanase (CMCase) and exo-glucanase (FPase) was very low. ${ }^{126}$ Observations using SEM showed the fungal surface colonization and loosening of wood fibers, and FT-IR indicated the chemical modification of eucalyptus wood, whilst DGGE on the last day of each pre-treatment period confirmed the presence of $C$. albidus, so that it was able to suppress the growth of a native population. ${ }^{126}$ Further, after 60 days of incubation, both control and treated eucalyptus wood chips were submitted to Kraft pulping. The $\mathrm{K} \mathrm{n}{ }^{\circ}$ for pulp of the control wood was 21 , whilst the $\mathrm{Kn}^{\circ}$ for the fungal pre-treated wood was 17 , showing that the biopulping with C. albidus was reduced the lignin content in eucalyptus wood, and it can be used in the pulp and paper industry. ${ }^{126}$

In Brazil, E. grandis wood chips have been biotreated by $C$. subvermispora in a 50-ton biopulping pilot-plant and used to produce TMP and CTMP pulps on a mill scale. Up to $18 \%$ and $27 \%$ energy savings have been observed for producing 450-470 CSF (Canadian Standard Freeness) TMP and CTMP pulps. Despite darker bio-TMP pulps are produced, one stage bleaching with $5 \% \mathrm{H}_{2} \mathrm{O}_{2}$ was sufficient to improve brightness values to 70 and $72 \%$ for bio TMP and control pulps respectively. ${ }^{108}$ 


\section{MYCOREMEDIATION}

Microorganisms constitute a powerful arm of environmental defense. The potential of existing microorganisms can be stimulated by the modification of the environment with some nutrients (biostimulation) or the contaminated environment can receive and addition of particular microorganisms (bioaugmentation) to improve the catabolism of specific compounds. Regarding to mycoremediation, it is an innovative biotechnological application that uses living fungi for in situ and ex situ clean-up and management of contaminated sites, since they play a broad variety of functions in ecosystem, breaking down long chain pollutants, natural or xenobiotic, into simpler less toxic chemicals and/or removing metals, metalloids and radionuclides (either by adsorption, chemical modification or by influencing chemical bioavailability) from soil and effluents. ${ }^{127}$ Especially fungi that are autochthonous for particular sites are effective as bioremediators, ${ }^{128,129}$ and their use may be a clean, simple and relatively inexpensive approach that needs only a small space, less skilled persons and can be applied easily in the field for environment correction. ${ }^{127}$

A study of the effect of a combined biostimulationbioaugmentation was performed with Rhizopus sp., Penicillium funiculosum and Aspergillus sydowii strains isolated from two aged soils contaminated with 60,600 and $500,000 \mathrm{mg}$ of a complex mixture of total petroleum hydrocarbons (TPH), which comprises $40 \%$ aliphatic hydrocarbons $(\mathrm{AH})$ and $21 \%$ polycyclic aromatic hydrocarbons $(\mathrm{PAH})$, per $\mathrm{kg}^{-1}$ dried soil. The native fungi were able to grow in a complex solid mixture of hydrocarbons of high molecular weight, after previous acclimatization in liquid culture, and they removed respectively $36 \%, 30 \%$ and $17 \%$ more $\mathrm{PAH}$ in comparison with biostimulation alone. ${ }^{129}$

The bioremediation using fungi (Table 3 ) has many advantages, although still is a challenge for the researchers and technics, since when it is carried out on site, it eliminates the need to transport the contaminated materials to treatment places, occurring immediate mitigation of odour and visible improvement of the soil or effluent safety (weeks to months), and even generating some interesting byproducts. ${ }^{127}$ The free range of phenolic compounds from biodegraded lignin, for instance, are potential substrates for bioconversion by $\omega$-transaminases $(\omega$-TAm) into valueadded chemicals: the CV2025 $\omega$-TAm from Chromobacterium violaceum DSM30191 was explored for selective amination using (S)- $\alpha$-methylbenzylamine (MBA) as the amino donor. Vanillin was identified as the best potential substrate which is converted into vanillylamine, an intermediate in the preparation of pelargonic acid vanillylamide used as a hyperemia inducing active substance in wound dressings. At low vanillin and MBA concentrations $\left(<10 \mathrm{mmol} \mathrm{L}^{-1}\right)$ and with an excess of the amine donor $(1: 4 \mathrm{~mol} / \mathrm{mol}) 100 \% \mathrm{w} / \mathrm{w}$ conversion of vanillin into vanillylamine was observed within $60 \mathrm{~min}$, and at vanillin concentrations $>10 \mathrm{mmol} \mathrm{L}^{-1}$, inhibition was observed, decreasing the rate and yield of the bioconversion and the presence of a byproduct (acetophenone). ${ }^{130}$

In contrast to the above, there are some disadvantages in applying this tool, since higher mushrooms or filamentous fungi require time to adapt to the substrates and clean-up wastes, and when cultivated on industrial pollutant material, may acquire toxicity/genotoxicity. In this case, it should be assessed that they will not serve as a food (higher mushrooms, as source or protein). ${ }^{127}$

Table 3. Role of fungi in biodegradation, biosorption or bioconvertion of pollutants. ${ }^{129,131-156}$

\begin{tabular}{|c|c|c|c|}
\hline Fungus & Waste/Pollutants & Remarks & References \\
\hline $\begin{array}{l}\text { Agaricus bisporus, } \\
\text { Lactarius piperatus }\end{array}$ & Cadmium (II) ions & $\begin{array}{l}\text { Wild } L \text {. piperatus showed higher } \\
\text { removal efficiency on } \mathrm{Cd}(\mathrm{II}) \text { ions } \\
\text { compared to the cultivated } A \text {. } \\
\text { bisporus }\end{array}$ & Nagy et al., 2013. ${ }^{131}$ \\
\hline $\begin{array}{l}\text { Allescheriella sp. DABAC1, } \\
\text { Stachybotrys sp. DABAC } 3 \text {, } \\
\text { Phlebia } \text { sp. DABAC9 } \\
\text { (autochthonous) }\end{array}$ & Heavily contaminated soil & $\begin{array}{l}\text { They produced laccase and MnP } \\
\text { and LiP in subalkaline pH condi- } \\
\text { tions due to heavy metal presence, } \\
\text { with removal of naphthalene, di- } \\
\text { chloroaniline isomers, o-hydroxy- } \\
\text { biphenyl, and 1,1'-binaphthalene; } \\
\text { Stachybotrys sp. DABAC } 3 \\
\text { depleted the 9,10-anthracenedione } \\
\text { and } 7 \mathrm{H} \text {-benz[DE] anthracen- } \\
7 \text {-one. Allescheriella } \text { sp. DABAC } \\
1 \text { or Stachybotrys sp. DABAC } 3 \\
\text { promoted release of chloride ions } \\
\text { in soil (oxidative dehalogenation). } \\
\text { Significant decrease in soil toxicity } \\
\text { (Lepidium sativum L. germination } \\
\text { and Collembola mortality tests). }\end{array}$ & D'Annibale et al., 2006. ${ }^{129}$ \\
\hline $\begin{array}{l}\text { Coriolus versicolor } \\
\text { MKACC } 52492\end{array}$ & $\mathrm{PAH}$ & $\begin{array}{l}\text { It degrades Poly-R } 478 \text { and } \\
\text { PAH. MnP, LiP and laccase were } \\
\text { produced }\end{array}$ & Jang et al., 2009. ${ }^{132}$ \\
\hline Fomes fasciatus & Copper (II) & $\begin{array}{l}\text { Efficient in biosorption of } \mathrm{Cu} \\
\text { (II) ions and hot-alkali treatment } \\
\text { increased their affinity for } \mathrm{Cu} \text { (II) } \\
\text { ions }\end{array}$ & Sutherland and Venkobachar, 2013. ${ }^{133}$ \\
\hline Flammulina velutipes & Copper & $\begin{array}{l}\text { Biosorbent for removing copper } \\
\text { ions from aqueous solution }\end{array}$ & Luo et al., 2013. ${ }^{134}$ \\
\hline Ganoderma sp & $\begin{array}{l}\text { Textile dyes Yellow, } \\
\text { Blue and Red Procion }\end{array}$ & $\begin{array}{l}\text { The biodegradation after } 72 \mathrm{~h} \text { at } \\
28^{\circ} \mathrm{C} \text { were } 33.6,43.5 \text { and } 57.7 \% \\
\text { for the dyes Yellow, Blue and Red } \\
\text { Procion, respectively }\end{array}$ & Barreto et al., 2011. ${ }^{135}$ \\
\hline
\end{tabular}


Table 3. Role of fungi in biodegradation, biosorption or bioconvertion of pollutants. ${ }^{129,131-156}$ (cont.)

\begin{tabular}{llll}
\hline Fungus & Waste/Pollutants & Remarks & References \\
\hline $\begin{array}{l}\text { Jelly sp., } \\
\begin{array}{l}\text { Schizophyllum commune and } \\
\text { Polyporous sp. }\end{array}\end{array}$ & Malachite green & $\begin{array}{l}99.75 \% \text { (Jelly sp.), 97.5\% } \\
\text { (Schizophyllum commune), 68.5\% } \\
\text { (Polyporous sp.2) dye was de- }\end{array}$ & Rajput et al., 2011. ${ }^{136}$ \\
\hline graded in 10 days & $\begin{array}{l}\text { It degrades 2,4-dichlorophenol } \\
\text { (DCP) by using vanillin as an } \\
\text { activator }\end{array}$ & Tsujiyama et al., 2013. ${ }^{137}$
\end{tabular}

Eucalyptus waste It converts this waste and qualitative and quantitative changes were measured

Vineyard pruning (VP), barley straw (BS), and wheat straw

\begin{tabular}{ll}
\hline Lentinula tigrinus & Wheat straw \\
\hline Pleurotus citrinopileatus & $\begin{array}{l}\text { Handmade paper and cardboard } \\
\text { industrial waste }\end{array}$ \\
\hline $\begin{array}{l}\text { Pleurotus eous and } \\
\text { Lentinus connotus }\end{array}$ & $\begin{array}{l}\text { Paddy straw, sorghum stalk, and } \\
\text { banana pseudostem }\end{array}$ \\
\hline Pleurotus florida & $\begin{array}{l}\text { Handmade paper and cardboard } \\
\text { industrial waste }\end{array}$ \\
\hline Pleurotus ostreatus & Oxo-Biodegradable plastic \\
& Cadmium \\
& Extract from the sawdust \\
\hline Pleurotus pulmonarius & Radioactive cellulosic-based waste \\
& \\
\hline Pleurotus sajor-caju & Crude oil \\
\hline & Heavy metal Zn \\
\hline
\end{tabular}

Pleurotus tuber-regium Heavy metals

Nigerian trees; Terminalia superba Mansonia altissima, Holoptelia grandis and Miliciaexcelsa

Cotton waste, sawdust of Khaya ivorensis and rice straw

\begin{tabular}{ll}
\hline $\begin{array}{l}\text { Pleurotus platypus, } \\
\text { Agaricus bisporus, } \\
\text { Calocybe indica }\end{array}$ & $\begin{array}{l}\text { Copper, Zinc, Iron, Cadmium, } \\
\text { Lead, Nickle }\end{array}$ \\
\hline $\begin{array}{l}\text { Volvariella volvacea } \\
\text { Banana leaves (Musa sapientum } \\
\text { lina) }\end{array}$ \\
$\begin{array}{l}\text { Agro-industrial residues such as } \\
\text { cassava, sugar beet pulp, wheat } \\
\text { bran and apple pomase }\end{array}$ \\
\end{tabular}
substrates
It converts VP waste with shortest primordium formation, highest biological efficiency, highest yield and shortest production cycle (6 days)

Production of lignocellulosic enzymes and bioconvertion of wheat straw

Basidiocarps possessed good nutri- $\quad$ Kulshreshtha et al., 2013. ${ }^{141}$ ent content and no genotoxicity

Waste successfully bioconverted Rani et al., 2008. ${ }^{142}$

by mushroom with good biological efficiency

Basidiocarps possessed normal
morphology and no genotoxicity

Kulshreshtha et al., 2010. ${ }^{143}$

It degrades the plastic and grew

on it.

Biosorption

da Luz et al., 2013. ${ }^{144}$

It produces biomass in submerged liquid culture were analyzed

Waste containing mushroom mycellium was solidified with portland cement and then this solidified waste act as first barrier against the release of radiocontaminants crude oil was degraded

Tay et al., 2011. ${ }^{145}$

Biosorb the heavy metals

Akinyele et al., 2012. ${ }^{146}$

Eskander et al., 2012. ${ }^{147}$

The production of ligninolytic enzymes was evident and a synergism among them being likely in the decolorizing process

Biosorb heavy metals from the soil $\quad$ Oyetayo et al., 2012. ${ }^{151}$ artificially contaminated

Grow on trees

Jonathan et al., 2008. ${ }^{152}$

Sclerotia propagated on groundnut shells and cocoyam peels with lipase and phenoloxidase; cellulase, carboxymethyl cellulase enzymatic activities

Kuforiji and Fasidi, 2008. ${ }^{153}$ Efficient biosorbent for the removal these ions from aqueous solution

Efficient bioconversion with good yield

Belewu and Belewu, 2005. ${ }^{155}$

Enzyme activities were measured during the fermentation of

Akinyele et al., 2011. ${ }^{156}$ 
As previously mentioned, the biodegradation mechanism is very complex due to the influence of other biochemical systems and interactions of ligninolytic enzymes with cytochrome $\mathrm{P}_{450}$ monooxygenase system, hydroxyl radicals and the level of $\mathrm{H}_{2} \mathrm{O}_{2}$ produced. However, the uptake of pollutants by fungi involves a combination of two strategies: (i) bioaccumulation, i.e., active metabolism-dependent processes, which includes both transport into the cell and partitioning into intracellular components; and (ii) biosorption, i.e., the binding of metallic ions/pollutants from effluent or soil to the polar groups of the surface molecules of the biomass, without requiring metabolic energy. Dead fungal biomass, for instance, offers certain advantages over living cells, and can be obtained from industries as a waste of fermentation processes. ${ }^{127}$ Heavy metal and radioactive cations, of course, cannot be decomposed but by a change in oxidation state, for instance, such as U (IV) (in $\mathrm{UO}_{2}$ ), they can be rendered into forms of low solubility, so that they remain less harmfully in the ground, or might be physically removed by plants or fungi through biosorption, which involves harvesting the plant or fungus, but on the other hand, this process generates non-consumable biomass, which gives rise to the new problem of disposing it. Therefore, in the case of remediation, preference should be given to those safety species which can remediate first a type of waste and further use for consumption. ${ }^{157}$

Before using a particular fungus in bioremediation, a four-phase analysis is necessary, it means, a bench-scale treatability, on-site pilot testing, production of inoculum, and finally full-scale application. Substrates such as wood chips, wheat straw, peat, corn cobs, sawdust, a nutrient-fortified mixture of grain and sawdust, bark, rice, annual plant stems and wood, fish oil, alfalfa, spent mushroom compost, sugarcane bagasse, coffee pulp, sugar beet pulp, okra, canola meal, cyclodextrins, and surfactants can be used in inoculum production both off-site or on-site, or as mixed with contaminated soils to improve the processes of degradation. It is critical to stablish the correct nitrogen/carbon ratio in the substrates used, avoiding any inhibition on the efficiency of the mycoremediation. Fungal inocula may be obtained by solid state fermentation or suffer encapsulation with alginate, gelatin, agarose, carrageenan, chitosan, etc., in the form of pellets, which may offer a better outcome than with inocula produced using bulk substrates. Such preparation methods enhance the likelihood of success in the first phase. ${ }^{158}$

The are many studies using mycoremediation in artificially contaminated sites spiked with organic pollutants, but the importance of researches under nonsterile conditions, with real contaminated soils/effluents, became more common in the last twenty years and made their results potentially transferable to a field scale, using biostimulation, bioaugmentation or, more recently, both technologies. This process depends on nutrient availability and the optimum presence of other factors that support biological functions, such as the concentration of the contaminants and their bioavailability, site characteristics, moisture, temperature, redox potential and oxygen content. ${ }^{158}$

Basidiomycetes are amongst nature's most powerful decomposers, secreting strong and low specificity catabolic extracellular enzymes from mycelium due to their aggressive growth and biomass production (they form extended mycelial networks to expand their surface area, what makes easier to contact the pollutant). Besides this, they are known due to their efficiency in producing food protein in the mycelia or fruiting bodies using different wastes as nutrients. ${ }^{159}$ Based on the literature about mycoremediation, whiterot basidiomycetes accounts for at least $30 \%$ of the total research on fungi used in this process, and $P$. chrysosporium, A. bisporus, Irpex lacteus, T. versicolor and Pleurotus ostreatus, $P$. tuberregium and $P$. pulmonarius, amongst many other basidiomycetes, have been reported in the decontamination of polluted sites. ${ }^{5,158}$ The biodegradation of vinasse by ligninolytic enzymes has been reviewed previously. ${ }^{160}$ Assays for vinasse decolorization were performed using the fungus Pleurotus sajor-caju CCB020 in vinasse biodegradation study, in which occurred reductions of $82.8 \%$ in COD, $75.3 \%$ in BOD, $99.2 \%$ in the coloration and $99.7 \%$ in turbidity. The vinasse toxicity reduction was determined by the exposition to the following organisms: Pseudokirchneriella subcapitata, Daphnia magna, Daphnia similis and Hydra attenuata. ${ }^{161}$

Sites polluted by recalcitrant organic compounds are also often contaminated by heavy metals, and in such a difficult case, the use of filamentous fungi (in particular, white-rot fungi) may give some advantages over autochthonous bacterial bioaugmentation. ${ }^{128}$ Allescheriella sp. DABAC-1, Stachybotrys sp. DABAC 3, and Phlebia sp. DABAC 9 were strains selected for remediation trials on the basis of Poly R-478 decolorization associated with ligninolytic enzymes production. These autochthonous fungi were tested for their abilities to grow under nonsterile conditions and to degrade various PAHs in the same contaminated soil. After 30 days, fungal colonization was clearly visible and confirmed by ergosterol determination. In spite of subalkaline $\mathrm{pH}$ conditions and the presence of heavy metals, the autochthonous fungi produced laccase, $\mathrm{MnP}$ and LiP. No ligninolytic activities were detected in control microcosms. All of the isolates led to a marked removal of naphthalene, dichloroaniline isomers, o-hydroxybiphenyl, and 1,1'-binaphthalene, being Stachybotrys sp. strain DABAC 3 the most effective due to its ability to partially deplete the predominant contaminants 9,10-anthracenedione and 7H-benz[DE] anthracen-7-one. A release of chloride ions was observed in soil treated with either Allescheriella sp. strain DABAC 1 or Stachybotrys sp. strain DABAC 3, suggesting the occurrence of oxidative dehalogenation. The autochthonous fungi also led to a significant decrease in soil toxicity. ${ }^{129}$

The effect of inoculation of soil microcosms with $T$. versicolor and $P$. chrysosporium on wood chips on differential degradation of pesticides (simazine, trifluralin and dieldrin, $10 \mathrm{mg} \mathrm{kg}^{-1}$ soil) at two water potentials $\left(-0.7\right.$ and $-2.8 \mathrm{MPa}$, at $\left.15^{\circ} \mathrm{C}\right)$ was studied through soil microcosms destructively sampled after $6 / 12$ weeks for determination of four extracellular enzymes, respiration and content of the pesticides. ${ }^{158}$ It was found that fungal treatments increased extracellular enzymes cellulase/dehydrogenase and laccase (mainly with $T$. versicolor), respiratory activity and degradation of the three pesticides by wood chip addition alone (20-30\%) in inoculated soil containing higher contents of pesticide mixtures. T. versicolor increased degradation of simazine $(27-46 \%)$, trifluralin $(5-17 \%)$ and dieldrin (5-11\%) after 12 weeks and P. chrysosporium by $34-48 \%, 0-30 \%$ and 40-46\%, respectively, when compared with controls, even at $-2.8 \mathrm{MPa}$ water potential, suggesting that effective bioremediation of xenobiotic mixtures using wood chips and fungal inoculants is achievable over a relatively wide water potential range when compared with that allowing plant growth $(-1.4 \mathrm{MPa}) .{ }^{162}$

Also, effluent originating from distilleries contain large amount of dark brown coloured wastewater called molasses spent wash which is the unwanted residual liquid waste to dispose because of low $\mathrm{pH}$, high temperature, dark brown colour, high ash content, unpleasant odour and high percentage of organic and inorganic matter. Dark brown colour of municipal solid waste (MSW) is due to the presence of melanoidin pigment. It reduces sunlight penetration in rivers and lakes which in turn decrease both photosynthetic activity and dissolved oxygen concentration affecting aquatic life. So, the disposal of this effluent is one of the critical environmental issues. Several treatment processes have been employed for the distillery waste management. Degradation and decolourization of these wastewater by chemical methods, flocculation treatment and physicochemical treatment such 
as ozonation and activated carbon adsorption have been accomplished, but these methods are not economically feasible on large scale due to cost limitation where as biological decolourization by using fungi such as Coriolus spp., Aspergillus spp., Phanerochaete spp. have been successfully achieved and thus can be applied as a bioremediation technique. ${ }^{163,164}$

$P$. chrysosporium has been known to degrade many types of organo-pollutants, such as polycyclic aromatic hydrocarbons (PAH's), polychlorinated biphenyls and dioxines, chlorophenols, chlorolignins, nitrocranditics, synthetic dyes and different pesticides, being a model for mycoremediation, since it is more efficient than other fungi or microorganisms in degrading toxic or insoluble materials because it presents simultaneous oxidative and reductive mechanisms, which permit its use in many different situations, both regarding the type of contamination, its degree, and the nature of the site itself. ${ }^{158}$ Biotreatment of bagasse effluent with high content of lignin using $P$. chrysosporium has shown that the best conditions of temperature, biomass concentration, $\mathrm{pH}$ and duration for this remediation were $35^{\circ} \mathrm{C}, 552 \mathrm{mg} \mathrm{l}^{-1}, 6$ and 5 to 9 days, respectively. Under these conditions, a 9 days long treatment reduced by $98.7 \%$ the original biochemical oxygen demand (of 2,780 $\mathrm{mg} \mathrm{l}^{-1}$ ) and by $98.5 \%$ the dissolved chemical oxygen demand (initial 4,200 $\mathrm{mg}^{-1}$ ). Moreover, fungal treatment reduced total dissolved solids from 3.950 to $575 \mathrm{mg} \mathrm{l}^{-1}$ and color from $560 \mathrm{mg} \mathrm{l}^{-1}$ PtCo to $111 \mathrm{mg} \mathrm{l}^{-1}$ PtCo. ${ }^{165}$ Recently, a niche opportunity to produce algal biofuel more cost effective carried out a research to make effluent of piggery anaerobic digestion an ideal medium for algal growth. The pre-treatment of the effluent became a challenge because of the requirement of non-toxic and eco-friendly methods compared to chemical reagents, and the clarity and N/P ratio are two crucial factors because light penetration and nutrient ratio influence the algal biomass accumulation. Hence, $P$. chrysosporium was chosen to deal with the digested effluent and the growth conditions were optimized by response surface method. The optimal conditions for the pretreatment by P. chrysosporium were $\mathrm{pH} 6.26,25{ }^{\circ} \mathrm{C}$ and an inoculum amount of $9.96 \mathrm{~mL}$. The decolorization and the reduction of total phosphorus reached 78.2 and $74.3 \%$, respectively, indicating the efficiency of the response surface method. The N/P ratio reached 14:1 and a COD reduction of $98.34 \%$ at $\mathrm{pH} 8$ at $35^{\circ} \mathrm{C}$ was reached, making $P$. chrysosporium is an effective microorganism to make the effluent from piggery anaerobic digestion an ideal medium for algal growth. ${ }^{166}$ Also, a composting study showed the degradation of 4-nonylphenol (4-NP) in river sediment by inoculating $P$. chrysosporium into composting Reactor A ( $\mathrm{t}_{1 / 2} 2079$ days), C ( $\mathrm{t}_{1 / 2} 2558$ days), and $\mathrm{D}$ ( $\mathrm{t}_{1 / 2} 2424$ days), while Reactor B without inocula ( $\mathrm{t}_{1 / 2} 3239$ days) was used as control. The results showed that composting with the fungus accelerated the degradation of 4-NP, increased the catalase and polyphenol oxidase enzyme activities in contaminated sediment. ${ }^{167}$ These examples clearly demonstrate that there is a need for further research towards the exploitation of potential of fungi as bioremediation tool.

\section{CONCLUSIONS}

In a world with uncontrolled industrial development and population growth, further efforts are needed to ensure the sustainability. Over recent decades, significant progress has been made in understanding fungal lignocellulose degradation and the great potential of fungi and their enzymes for biotechnological approaches aiming good productions and clean environmental. The pulping and paper industry, looking for a more sustainable development, has been studying biological replacements for some of the chemicals used in their procedures. Pre-treating different lignocellulolytic material (wood or agricultural residues), prepared for pulping processes, with cellulose and hemicellulose fungal enzymes has carried out to a certain success. The main result from the use of xylanases, for instance, is a selective decreasing of the hemicellulose content in dissolving pulp, improving yield, reducing the volume of the chemicals used during the process, and minimizing the consume of electrical energy (at least 30\%). On the other hand, several wood-rot fungi produce many extracellular oxidative enzymes able to initiate delignification and biobleaching of the Kraft pulp, causing its extensive brightness, such the MnP. Also, wood-degrading fungi are extremely effective in sorbing/accumulating toxic molecules, such as heavy metals, in decomposing lignin-like compounds (natural or xenobiotic), or in converting them in sellable products, in situ or ex situ. Therefore, the use of fungi ise in the forefront of biotechnological research as effective alternative (low expensive, efficient, not pollute and able to improve properties of degraded fiber furnishes) to the traditional pulping and bleaching methods, as well as is actually becoming more popular for remediation purposes, including that they also provide byproducts cleaning industrial and agro-industrial wastes. In this way, the role of fungal enzymes in the degradation of lignin and pulp and paper mill effluents, and dyes must be better exploited by researchers working with bioremediation.

\section{ACKNOWLEDGEMENTS}

We thank to the "S.A. Usina Coruripe Açúcar e Álcool", the CNPq and CAPES for the financial support of our projects and to Dr. Dennis de Oliveira Imbroisi, from the IQB/UFAL-Brazil, for reviewing Figure 1.

\section{REFERENCES}

1. http://tissueonline.com.br/bracelpa-producao-de-celulose-e-de-papel-semantem-em-alta/, accessed May 2017.

2. https://www.papnews.com/exports-of-pulp-wood-panels-and-paperincrease-in-2015/, accessed May 2017

3. Shukla, O. P.; Rai, U. M.; Subramanyam, S. V.; Newsletter of ISEB India 2004.

4. Ja'afaru, M. I.; ISRN Microbiol. 2013

5. Adenipekun, C. O.; Lawal, R.; Biotechnol. Mol. Biol. Rev. 2012, 7, 62.

6. Ruiz-Dueñas, F. J.; Martínez, M. J.; Microb. Biotechnol. 2009, $2,164$.

7. Singh, P.; Sulaiman, O.; Hashim, R.; Rev. Environ. Sci. Biotechnol. 2010, 9, 141.

8. Stevens, F. In Properties of Fibrous Raw Materials and Their Preparation for Pulping; Kocurek, M. J., Stevens, F., eds.; TAPPI: Minessota, 1983.

9. Youngquist, J. A.; Spelter, H.; English, B. E, Chow, P. In Agricultural fibres in composition panels; Maloney, T. M., ed.; Pullman: Washington, 1993.

10. Khalil, A.S.; Alwani, M.S.; Omar, A.M.; Bioresources 2006, 1, 220.

11. Taylor, T. N.; Osborne, J. M.; Review of Palaeobotany and Palynology 1996, 90, 249.

12. Liers, C.; Arnstadt, T.; Ullrich, R.; Hofrichter, M.; FEMS Microbiol. Ecol. 2011, 78, 91.

13. Thakur, M.; Asian J. Environ. Sci. 2014, 9, 24.

14. Aguiar, A.; Ferraz, A.; Quim. Nova 2011, 34, 1729.

15. Kersten, P.; Cullen, D.; Fungal Genet. Biol. 2007, 44, 77.

16. Martínez, A.T.; Enzyme Microb. Technol. 2002, 30, 425.

17. Hammel, K.E.; Cullen, D. Curr. Opin. Plant. Biol. 2008, 11, 349

18. Martínez, D.; Larrondo, L.F.; Putnam, N. Gelpke. M. D.; Huang, K.; Chapman, J.; Helfenbein, K.G.; Ramaiya, P.; Detter, J.C.; Larimer, F.; Coutinho, P.M.; Henrissat, B.; Berka, R.; Cullen, D.; Rokhsar, D.; Nat. Biotechnol. 2004, 22, 695. 
19. Martínez, A. T.; Camarero, S.; Guillén, F.; Gutiérrez, A.; Muñoz, C.; varela, E.; Martínez, M. J.; Barrasa, J. M.; Ruel, K.; Pelayo, J. M.; FEMS Microbiol. Rev. 1994, 13, 265.

20. Bao, W.L.; Fukushima, Y.; Jensen, K.A.; Moen, M. A.; Hammel, K. E.; FEBS Lett. 1994, 354, 297.

21. Morgenstern, I.; Klopman, S.; Hibbett, D. S.; J. Mol. Evol. 2008, 66, 243.

22. Dashtban, M.; Schraft, H.; Syed, T.A.; Wensheng, Q.; Int. J. Biochem. Mol. Biol. 2010, 1, 36 .

23. Kirk, T. K.; Farrell, R. L.; Annu. Rev. Microbiol. 1987, 41, 465.

24. Gutiérrez, A.; Caramelo, L.; Prieto, A.; Martínez, M. J.; Martínez, A. T.; Appl. Environ. Microbiol. 1994, 60, 1783.

25. Kersten, P.; Cullen, D.; Fungal Genet. Biol. 2007, 44, 77.

26. Guillén, F.; Evans, C. S.; Appl. Environ. Microbiol. 1994, 60, 2811.

27. Cullen, D.; J. Biotechnol. 1997, 53, 273.

28. Martinez, D.; Challacombe, J.; Morgenstern, I.; Hibbett, D.; Schmoll, M.; Kubicek, C. P.; Ferreira, P.; Ruiz-Duenas, F. J.; Martinez, A. T.; Kersten, P.; Hammel, K. E.; Vanden Wymelenberg, A.; Gaskell, J.; Lindquist, E.; Sabat, G.; Bondurant, S. S.; Larrondo, L. F.; Canessa, P.; Vicuna, R.; Yadav, J.; Doddapaneni, H.; Subramanian, V.; Pisabarro, A. G.; Lavín, J. L.; Oguiza, J. A.; Master, E.; Henrissat, B.; Coutinho, P. M.; Harris, P.; Magnuson, J. K.; Baker, S. E.; Bruno, K.; Kenealy, W.; Hoegger, P. J.; Kües, U.; Ramaiya, P.; Lucas, S.; Salamov, A.; Shapiro, H.; Tu, H.; Chee, C. L.; Misra, M.; Xie, G.; Teter, S.; Yaver, D.; James, T.; Mokrejs, M.; Pospisek, M.; Grigoriev, I. V.; Brettin, T.; Rokhsar, D.; Berka, R.; Cullen, D.; Proc. Natl. Acad. Sci. U. S. A. 2009, 106, 1954.

29. FernándezFueyo, E.; RuizDueñas, F. J.; López Lucendo, M. F.; Pérez Boada, M.; Rencoret, J.; Gutiérrez, A.; Pisabarro, A. G.; Ramírez, L.; Martínez, A. T.; Biotechnol. Biofuels 2016, 9, 1.

30. Sharma, P.; Goel, R.; Capalash, N.; World J. Microbiol. Biotechnol. 2007, 23, 823 .

31. Claus, H.; Micron 2004, 35, 93.

32. Hatakka, A.; Hammel, K. E. In Fungal biodegradation of lignocelluloses; Hofrichter, M., ed.; Springer-Verlag: Berlin, 2010.

33. Nogueira, R. F. P.; Trovó, A. G.; Silva, M. R. A.; Villa, R. D.; Oliveira, M. C.; Quim. Nova 2007, 30, 400.

34. Guillén, F.; Gómez-Toribio, V.; Martínez, M. J.; Martínez, A. T.; Arch Biochem. Biophys. 2000, 383, 142.

35. Sixta, H.; Preface: Handbook of Pulp 1. Wiley-VCH Verlag \& Co KGaA: Weinheim, 2006.

36. Marella, J. B. R.; Madireddy, S.; Maripi, A. N.; Int. J. Eng. Res. Gen. Sci. 2014, 2, 61 .

37. Henriksson, G.; Teeri, T. In Biotechnology in the forest industry; Monica, E., Göran, G., Gunnar, H., eds.; Walter de Gruyter: Berlin, 2009.

38. Scott, G. M.; Akhtar, M.; Swaney, R. E.; Houtman, C. J. In Recent Developments in Biopulping Technology at Madison, WI; Viikari, L., Lantto, R., eds.; Elsevier Science: Amsterdam, 2002.

39. Raghukumar, C.; Muraleedharan, U. D.; Goud, V. R.; Mishra, R.; J. Ind. Microbiol. Biotechnol. 2004, 31, 433.

40. Otjen, L.; Blanchette, R. A.; Effland, M.; Leatham, G.; Holzforschung $\mathbf{1 9 8 7}, 41,343$.

41. Job-Cei, C.; Keller, J.; Job, D.; Mater. Organ. 1991, 26, 215.

42. Blanchette, R. A.; Burnes, T. A.; Eerdmans, M. M. Akhtar, M.; Holzforschung 1992, 46, 109.

43. Bechtold, R.; Gonzales, A. E.; Almendros, G.; Martínez, M. J.; Martínez, A. T.; Holzforschung 1993, 47, 91.

44. Oriaran, T. P.; Labosky, P.; Blankenhorn, P. R.; Wood Fiber Sci. 1991, 23,316 .

45. Blanchette, R. A.; Can. J. Bot. 1995, 1, 999.

46. Daniel, G.; Nilsson, T. In Developments in the study of soft rot and bacterial decay; Bruce, A., Palfreyman, J. W., eds.; Taylor \& Francis: Great Britain, 1998.
47. Nilsson, T.; Daniel, G.; Holzforschung 1989, 43, 11.

48. Rodriguez, A.; Falcón, M. A.; Carnicero, A.; Perestelo, F.; De la Fuente, G.; Trojanowski, J.; Appl. Microbiol. Biotechnol. 1996, 45, 399.

49. Regalado, V.; Rodriguez, A.; Perestelo, F.; Carnicero, A.; De la Fuente, G.; Falcón, M. A.; Appl. Environ. Microbiol. 1997, 63, 716.

50. Tuomela, M.; Vikman, M.; Hatakka, A.; Itåvaara, M.; Bioresour. Technol. 2000, 72, 169.

51. Hamed, S. A.; Int. Biodeterior. Biodegrad. 2013, 78, 98.

52. Hofrichter, M.; Fritsche, W.; Appl. Microbiol. Biotechnol. 1996, 46, 220.

53. Chefetz, B.; Kerem, Z.; Chen, Z.; Hadar, Y.; Soil Biol. Biochem. 1998, 30, 1091.

54. Li, K.; Xu, F.; Eriksson, K.; Appl. Environ. Microbiol. 1999, 65, 2654.

55. Machuca, A.; Milagres, A. M. F.; Aoyama, H.; Duran, N.; $4^{\text {th }}$ Brazilian Symposium on the Chemistry of Lignins and Other Wood Components. Recife, Brazil, 1995.

56. Machuca, A.; Aoyama, H.; Duran, N.; Biotechnol. Appl. Biochem. 1998, 27, 217.

57. Alexopoulos, C. J.; Mims, C. W.; Blackwell, M.; Introductory mycology, Wiley: New York, 1996.

58. Blackwell, M.; Am. J. Bot. 2011, 98, 426.

59. Eriksson, K. E.; Blanchette, R. A.; Ander, P. In Biodegradation of lignin; Timell, T. E., ed.; Springer-Velag GmbH \& Co. KG: Berlin, 1990.

60. Schilling, J. S.; Tewalt, J. P.; Duncan, S. M.; Appl. Microbiol. Biotechnol. 2009, 84, 465.

61. Dey, S.; Maiti, T.; Bhattacharyya, B. C.; Appl. Environ. Microbiol. 1994, 60, 4216

62. D’Souza, T. M.; Boominathan, K.; Reddy, C. A.; Appl. Environ. Microbiol. 1996, 62, 3739.

63. Arantes, V.; Goodell, B. In Current Understanding of Brown-Rot Fungal Biodegradation Mechanisms: A Review; Schultz, T. P.; Goodell, B.; Nicholas, D. D., eds.; American Chemical Society: Washington, 2014, cap. 1.

64. Halis, R.; Tan, H.R.; Zaidon, A.; Rozi, M.; BioResources 2012, 7 , 984.

65. Jin, L.; Nicholas, D. D.; Kirk, T. K.; Wood Sci. Technol. 1990, 24, 263.

66. Kirk, T. K.; Holzforschung 1975, 29, 99.

67. Jin, L.; Schultz, T. P.; Nicholas, D. D.; Holzforschung 1990, 44, 133.

68. Agosin, E.; Jarpa, S.; Rojas, E.; Espejo, E.; Enzyme Microb. Technol. 1989, 11, 511

69. Evans, C. S.; Dutton, M. V.; Guillen, F.; Veness, R. G.; FEMS Microbiol. Rev. 1994, 13, 235.

70. Wood, P. M.; FEMS Microbiol. Rev. 1994, 13, 313.

71. Goodell, B.; Jellison, J.; Liu, J.; Daniel, G.; Paszczynski, A.; Fekete, F.; Krishnamurthy, L. J.; Xu, G.; J. Biotechnol. 1997, 53, 133.

72. Shimada, M.; Akamtsu, Y.; Tokimatsu, T.; Mii, K.; Hattori, T.; J. Biotechnol. 1997, 53, 103.

73. Koenigs, J. W.; Arch. Microbiol. 1974, 99, 129.

74. Fekete, F.; Chandhoke, V.; Jellison, J.; Appl. Environ. Microbiol. 1989, $55,2720$.

75. Espejo, E.; Agosin, E.; Appl. Environ. Microbiol. 1991, 57, 1980.

76. Jellison, J.; Chandhoke, V.; Goodell, B.; Fekete, F. A.; Appl. Microbiol. Biotechnol. 1991, 35, 805.

77. Enoki, A.; Itakura, S.; Tanaka, H.; J. Biotechnol. 1997, 53, 265.

78. Kerem, Z.; Jensen, K. A.; Hammel, K. E.; FEBS Lett. 1999, 446, 49.

79. Paszczynski, A.; Crawford, R.; Funk, D.; Goodell, B.; Appl. Environ. Microbiol. 1999, 65, 674.

80. Hyde, S. M.; Wood, P. M.; Microbiology 1997, 143, 259.

81. Davis, M.; Schroeder, H. A.; Maciel, G. E.; Holzforschung 1994, 48, 301.

82. Niemenmaa, O. V; Uusi-Rauva, A. K.; Hatakka, A. I.; Biodegradation 2008, 19, 555.

83. Aguiar, A.; Ferraz, A.; Quim. Nova 2012, 35, 1107.

84. Messner, K.; Srebotnik, E.; FEMS Microbiol. Rev. 1994, 13, 351. 
85. Jennings, D. H.; The physiology of fungal nutritio, $1^{\text {th }}$ ed., Cambridge University Press: Cambridge, 1995.

86. Scott, G. M.; Akhtar, M.; Lentz, M. J.; Swaney, R.; Tappi J. 1998, 81, 220.

87. Otjen, L.; Blanchette, R. A.; Appl. Environ. Microbiol. 1985, 50, 568.

88. Wolfaardt, F.; Taljaard, J. L.; Jacobs, A.; Male, J. R.; Rabie, C. J.; Bioresource Technol. 2004, 95, 25.

89. Hakala, T. K.; Lundell, T.; Galkin, S.; Maijala, P.; Kalkkinen, N.; Hatakka, A.; Enzyme Microb. Technol. 2005, 3, 461.

90. Ander, P.; Eriksson, K. E.; Physiol. Plant. 1977, 41, 239.

91. Dorado, J.; Almendros, G.; Camarero S.; Martínez, A. T.; Vares, T.; Hatakka, A.; Enzyme Microb. Technol. 1999, 25, 605.

92. Fackler, K.; Gradinger, C.; Hinterstoisser, B.; Schwanninger, M.; Enzyme Microb. Technol. 2006, 39, 1476.

93. Blanchette, R. A.; Appl. Environ. Microbiol. 1984, 48, 647.

94. Akhtar, M.; Blanchette, R. A.; Myers, G.; Kirk, T. K. In Environmentally Friendly Technologies for Pulp and Paper Industries; Young, R. A.; Akhtar, M., eds.; Wiley: New York, 1998, cap. 10.

95. Gilbertson, R. L.; Mycologia 1980, 72, 1.

96. Burlat, V.; Joseleau, J. P.; Ruel, K. In Topochemistry and microdiversity of lignin in plant cell walls; Kim, Y. S., ed.; Kwangju: Korea, 2000.

97. Gold, M. H.; Alic, M.; Microbiol. Rev. 1993, 57, 605.

98. D'Souza, T. M.; Merritt, C. S.; Reddy, C. A.; Appl. Environ. Microbiol. 1999, 65, 5307.

99. Steffen, K. T.; Hofrichter, M.; Hatakka, A.; Appl. Microbiol. Biotechnol. 2000, 54,819

100. Bonnen, A. M.; Anton, L. H.; Orth, A. B.; Appl. Environ. Microbiol. 1994, 60, 960

101. Dedeyan, B.; Klonowska, A.; Taggar, S.; Tron, T.; Lacazio, G.; Gil, G.; Le petit, J.; Appl. Environ. Microbiol. 2000, 66, 925.

102. Nieschlag, H. J.; Nelson, G. H.; Wolff, I. A.; Tappi J. 1960, 43, 93.

103. Kordsachia, O.; Baum, N.; Patt, R.; Das Papier 1992, 46, 257.

104. Olsson, R.; Torgilsson, R; Burvall, J.; Pira International / Silsoe Research Institute Joint Conference, Leatherhead, UK, 1994.

105. Pahkala, K.; Masters Dissertation, University of Helsinki, Filand, 2001.

106. Madakadze, I. C.; Masamvu, T. M.; Radiotis, T.; Li, J.; Smith, D. L.; Afr. J. Environ. Sci. Technol. 2010, 4, 465.

107. http://faostat3.fao.org/download/Q/QC/E, accessed May 2017.

108. Ferraz, A.; O Papel 2007, 68, 44.

109. Singhal, A.; Jaiswal, P. K.; Thakur, I. S.; Int. Biodeterior. Biodegrad. 2015, 97, 143.

110. Goel, H. K.; Eisner, R.; Sherson, G.; Li, J.; Switch grass a potential pulp fibre source, $84^{\text {th }}$ ed., Canadian: Montreal, 1998.

111. Shah, M.; Reddy, G. V.; Banerjee, R.; Babu, P. R.; Kothari, I. L.; Proc. Biochem. 2005, 40, 445.

112. Osma, J. F.; Saravia, V.; Herrera, J. L. T.; Rodríguez Couto, S.; Chemosphere 2007, 67, 1677 .

113. Rodríguez Couto, S.; Toca Herrera, J. L.; Biotechnol. Adv. 2006, 24, 500.

114. Arias, M. E.; Rodríguez, J.; Pérez, M. I.; Hernández, M.; Polvillo, O.; González-Pérez, J. A.; González-Villa, F. J.; Wood Sci. Technol. 2010, 44, 179.

115. Leathem, G. F.; Myers, G. C.; Wegner, T. H.; Tappi J. 1990, 73, 197.

116. Rajan, A.; Resmi, C. S.; Pavithran, C.; Abraham, T. E.; Bioprocess Biosyst. Eng. 2005, 28, 165.

117. Akhtar, M.; Attridge, M. C.; Myers, G. C.; Blanchette, R. A.; Tappi J. 1992, 75, 105 .

118. Akhtar, M.; Attridge, M. C.; Myers, G. C.; Blanchette, R. A.; Holzforschung 1993, 47, 36.

119. Bugg, T. D.; Ahmad, M.; Hardiman, E. M.; Rahmanpour, R.; Nat. Prod. Rep. 2011, 28, 1883.

120. Albert, S.; Padhiar, A.; Int. J. Appl. Biol. Pharm. Technol. 2012, 3, 369.

121. Terashima, N.; Fukushima, K.; He, L-F.; Takabe, K. In Comprehensive model of the lignified plant cell wall; Jung, H. G.; Buxton, D. R.;
Hatfield, R. D.; Ralph, J., eds.; Forage Cell Wall Structure and Digestibility: Madison, 1993, cap. 10.

122. Van Soest, P. J.; Wine, R. H.; J. - Assoc. Off. Anal. Chem. 1968, 51, 780.

123. Nayan, N. H. M.; Razak, S. I. A.; Rahman, W. A. W. A.; Adv. Mat. Res. 2014, 1043, 180.

124. Risdianto, H.; Sugesty, S.; Mod. Appl. Sci. 2015, 9, 1.

125. Singh, P.; Sulaiman, O.; Hashim, R.; Peng, L. C.; Singh, P. R.; Int. Biodeterior. Biodegrad. 2013, 82, 96.

126. Singhal, A.; Jaiswal, P. K.; Jha, P. K.; Thapliyal, A.; Thakur, I. S.; Prep. Biochem. Biotechnol. 2013, 43,735.

127. Kulshreshtha, S.; Mathur, N.; Bhatnagar, P.; AMB Express 2014, 4, 1.

128. D’Annibale, A.; Rosetto, F.; Leonardi, V.; Federici, F.; Petruccioli, M.; Appl. Environ. Microbiol. 2006, 72, 28.

129. Mancera-López, M. E.; Esparza-García, F.; Chávez-Gómez, B.; Rodríguez-Vázquez, R.; Saucedo-Castañeda, G.; Barrera-Cortés, J.; Int. Biodeterior. Biodegrad. 2008, 61, 151.

130. Du, C. J.; Rios-Solis, L.; Ward, J. M.; Dalby, P. A.; Lye, G. J.; Biocatal. Biotrans. 2014, 32, 302.

131. Nagy, B.; Măicăneanu, A.; Indolean, C.; Mânzatu, C.; SilaghiDumitrescu, M. C.; J. Taiwan Inst. Chem. Eng. 2014, 45, 921.

132. Jang, K. Y.; Cho, S. M.; Seok, S. J.; Kong, W. S.; Kim, G. H.; Sung, J. M.; Mycobiology 2009, 37, 53.

133. Sutherland, C.; Venkobachar, C.; Int. J. Plant, Anim. Environ. Sci. 2013, $3,193$.

134. Luo, D. Y f. X.; Tan, Z. L.; Li, X. D.; J. Environ. Biol. 2013, 34, 359.

135. Barreto, W. J.; Bernardino, N. D.; Afonso, R.; Quim. Nova 2011, 34, 568.

136. Tsujiyama, S.; Muraoka, T.; Takada, N.; Biotechnol. Lett. 2013, 35, 1079 .

137. Brienzo, M.; Silva, E. M.; Milagres, A. M.; Appl. Biochem. Biotechnol. 2007, 141, 37.

138. Gaitán-Hernández, R.; Esqueda, M.; Gutiérrez, A.; Sánchez, A.; Beltrán-García, M.; Mata, G.; Appl. Microbiol. Biotechnol. 2006, 71, 432.

139. Lechner, B. E.; Papinutti, V. L.; Process Biochem. 2006, 41, 594.

140. Rajput, Y.; Shit, S.; Shukla, A.; Shukla, K.; J. Exp. Sci. 2011, 2, 69.

141. Kulshreshtha, S.; Mathur, N.; Bhatnagar, P.; Kulshreshtha, S.; Ind. Crops Prod. 2013, 41, 340

142. Rani, P.; Kalyani, N.; Prathiba, K.; Appl. Biochem. Biotechnol. 2008, 151,151 .

143. Kulshreshtha, S.; Mathur, N.; Bhatnagar, P.; Jain, B. L.; J. Environ. Biol. 2010, $31,441$.

144. Da Luz, J. M. R.; Paes, S. A.; Nunes, M. D.; da Silva, M. C. S.; Kasuya, M. C. M.; PLoS One 2013, 8, 69386,

145. Tay, C. C.; Liew, H. H.; Yin, C. Y.; Abdul-Talib, S.; Surif, S.; Suhaimi, A. A.; Yong, S. K.; Korean J. Chem. Eng. 2011, 28, 825.

146. Akinyele, J. B.; Fakoya, S.; Adetuyi, C. F.; Malaysian J. Microbiol. 2012, 8,135

147. Eskander, S. B.; Abd El-Aziz, S. M.; El-Sayaad, H.; Saleh, H. M.; ISRN Chem. Eng. 2012, 2012, 1.

148. Olusola, S. A.; Anslem, E. E.; J. Bioremed. Biodegrad. 2010, 1, 111.

149. Jibran, A. K.; Milsee Mol, J. P.; Adv. Biotech. 2011, 11, 25.

150. Kamida, H. M.; Durránt, L. R.; Monteiro, R. T. R.; Armas, E. D.; Quim. Nova 2005, 28, 629.

151. Oyetayo, V. O.; Adebayo, A. O.; Ibileye, A.; Int. J. Adv. Biol. Res. 2012, $2,293$.

152. Jonathan, S. G.; Fasidi, I. O.; Ajayi, A. O.; Adegeye, O.; Bioresour. Technol. 2008, 99, 807

153. Kuforiji, O. O.; Fasidi; I. O.; Bioresour. Technol 2008, 99, 4275.

154. Lamrood, P. Y.; Ralegankar, S. D.; Asian J. Exp. Biol. Sci. 2013, 4, 190.

155. Belewu, M. A.; Belewu, K. Y.; Afr. J. Biotechnol. 2005, 4, 1401.

156. Akinyele, B. J.; Olaniyi, O. O.; Arotupin, D. J.; Res. J. Microbiol. 2011, 6,63 . 
157. Singh, G.; Sengor, S. S.; Bhalla, A.; Kumar, S.; De, J.; Stewart, B.; Spycher, N.; Ginn, T. M.; Peyton, B. M.; Sani, R. K.; Crit. Rev. Environ. Sci. Technol. 2014, 44, 391.

158. Rhodes, C. J.; Chem. Speciation Bioavailability 2014, 26, 196.

159. Zhu, M. J.; Du, F.; Zhang, G. Q.; Wang, H. X.; Ng, T. B.; Biodeterior. Biodegrad. 2013, 4, 33.

160. Romanholo, L. F. F; López, A. M. Q.; Monteiro, R. T. R.; Ruzene, D. S.; Silva, D. P.; Fungal Enzymes, $1^{\text {st }}$ ed., CRC Press: USA, 2013.

161. Romanholo, L. F. F; Aguiar, M. M.; Messias, T. G.; Pompeu, G. B.; López, A. M. Q.; Silva, D. P.; Monteiro, R. T.; Ecotoxicol. Environ. Saf. 2011, 74, 132.

162. Fragoeiro, S.; Magan, N.; Biodeterior. Biodegrad. 2008, 62, 376.
163. Fujita, M.; Era, A.; Ike, M.; Soda, S.; Miyata, N.; Hirao, T.; Biosci. Bioeng. 2000, 90, 387.

164. Guimaraes, C.; Porto, P.; Oliveira, R.; Mota, M.; Process Biochem. 2005, $40,535$.

165. Sharari, M.; Latibari, J. A.; Guillet, A.; Aurousseau, M.; Mouhamadou, B.; Rafeiee, G. H.; Mirshokraei, A.; Parsapaghouh, D.; Biodeterior. Biodegrad. 2011, 22, 421.

166. Liu, J.; Song, Y.; Ruan, R.; Liu, Y.; CLEAN - Soil, Air, Water 2015, 43, 1190 .

167. Huang, D.; Qin, X.; Xu, P.; Zeng, G.; Peng, Z.; Wang, R.; Wan, J.; Gong.; Xue, W.; Bioresour. Technol. 2016, 221, 47. 